\title{
LIETUVOS KARIUOMENĖS TECHNIKA: SUNKVEŽIMIAI
}

\section{Vidas Grigoraitis}

Straipsnio tikslas - trumpai apžvelgti tarpukario Lietuvos kariuomenès sunkiojo transporto - pirmujų sunkvežimių - įsigijimo, registravimo, naudojimo, kareivių vairuotojų mokymo kariuomenès egzistavimo metu bei šio transporto likimo šali okupavus ir aneksavus reikalus.

Kaip ir kiekvienos kitos šalies kariuomenėje, taip ir Lietuvos, sunkvežimiai buvo naudojami ịvairiems darbams. Nuo to, kuriai kariuomenės rūšiai sunkvežimiai buvo priskirti - artilerijos, aviacijos, sanitarijos, inžinerijos ar autorinktinei, - priklausė ir su jais atliekamo darbo specifika. Pagrindinis darbas - kareivių ir krovinių, maisto, inžinerinių įrengimų pervežimas, artilerijos pabūklų ir šaudmenų transportavimas bei visi kiti kareiviškos kasdienybès padiktuoti darbai.

Apie Lietuvos kariuomenès transportą savo straipsnyje yra trumpai užsiminę A.Kasperavičius ir T.Mieliauskas ${ }^{1}$, apžvelgdamas kariuomenès genezę, apie automobilių transportą yra rašęs G.Surgailis ${ }^{2}$. Atskiro straipsnio vien apie Lietuvos kariuomenès sunkiojo transporto naudojimą nèra, išskyrus šio straipsnio žurnalistinị variantą ${ }^{3}$.

Kariuomenès inžinerijos kuopoje Kaune 1919 m. sausio 30 d. įsteigiamas pirmasis Lietuvos kariuomenės automobilių transporto junginys - automobilių būrys. Nuo kovo $1 \mathrm{~d}$. automobilių būrys tampa kuopa, o nuo balandžio $30 \mathrm{~d}$. - atskira automobilių kuopa ${ }^{4}$. Pirmuoju junginių vadovu tapo buvęs carinès kariuomenès karininkas, vẻliau - Lietuvos kariuomenès karininkas Sergejus Fanstelis ${ }^{5}$. Pasikeičia ir kuopos dislokacijos vieta - persikeliama ị namą Donelaičio ir Maironio gatvių susikirtime.

\footnotetext{
${ }^{1}$ A. Kasperavičius,T.Mieliauskas Lietuvos -Lenkijos santykiai ir Lietuvos kariuomenès modernizavimas 1926-1939 metais,Karo archyvas XV,Lietuvos krašto apsaugos ministerija,1998 m. ps1144-160.

${ }^{2}$ G.Surgailis Lietuvos kariuomenè 1918-1998, Vilnius 1998,psl.50-51.

${ }^{3}$ V.Grigoraitis Lietuvos kariuomenès sunkvežimiai, Mobilis,2000 m. Nr.6,psl.40-45.

${ }^{4}$ Isakymas Krašto apsaugos ministerijai Nr.63, Kaunas, 1919 m. balandžio 7 d.

5 Tarnybos byla, LCVA,F.930,AP.2,B.2,L.1-25.
} 
Lietuvos kariuomenès transporto technikos ịsigijimo ir naudojimo pradžia laikytina 1919 m. gegužès 22 d., kai kariuomenès garažuose atsirado pirmieji septyni lengvieji automobiliai. Pirmas automobilių sąraše buvo įrašytas vokiškas šešiavietis "Daimler 10/20" markès lengvasis automobilis 6 , po vieną "Loreley 12/32", "Hansa 12/36" ir "Opel 10/24", "Opel 14/30", "Opel 18/45", "Opel 20/45" markès automobilị. Visi šie kariškių įsigyti automobiliai buvo pirkti Karaliaučiuje iš Vokietijos kariuomenès ir pargabenti ị Kauną. Kartu su lengvaisiais automobiliais buvo nupirkta atsarginių detalių, padangų, tepalo $^{7}$. Neturẻdama kitu galimybių pirkti naujus automobilius, kariuomenè juos stengėsi igyti pirkdama iš kraštą paliekančių vokiečių arba išmainydama.

Isigijus pirmuosius lengvuosius automobilius, kariškiams teko pradèti rūpintis ir sunkiojo transporto pirkimu, nes buvo vairuotojų, o transporto neturèta. Netrukus, tụ pačių $1919 \mathrm{~m}$. birželio 17 d., nuperkamas pirmas kariuomenès sunkvežimis "Fiat". Šis sunkvežimis turèjo keturių cilindru varikli, jo keliamoji galia buvo 1,5 t. Automobilis buvo naudotas, neveikè tepalo siurblys, o iš sulankstyto radiatoriaus tekėjo vanduo $^{8}$.

Sparčiai augančiai kariuomenei reikejjo pirkti ir daugiau sunkvežimių. Iš firmos "Banga" 1919 m. liepos 3 d. nuperkami keturi triju tonų krovos, 30 AJ galios "Arbenc" sunkvežimiai. Prieš perduodant eksploatuoti kuopai, visi sunkvežimiai buvo išbandyti ir nustatyta, jog "mėginant variklius pasirodé, kad jie veikia gerai" ir "i kalną su pilnu tonažu visos mašinos užèjo [...] trečiu greitumu".

Prièmimo komisijai vadovavo automobilių kuopos vadas S.Fanstilis, jos darbe dalyvavo karininkas K.Rodovič, inžinerijos karo valdininkas Godlevskis bei Valstybès kontrolès atstovas J.Rymša. Vis dèlto ne visi komisijos nariai buvo patenkinti nupirktos technikos būkle, tad vienas iš priëmimo komisijos narių prièmimo akte ịrašè išvadą, kad "mašinos padyrbtos iš neatatinkančios medžiagos ir tokių būdū tarnauti ylga laika ne gales" .

\footnotetext{
71919 m.gegužès 22 d. prièmimo aktas,LCVA,F.532,AP.1,B.7,L.12.

${ }^{8} 1919$ m. birželio 17 d. prièmimo aktas,LVCA,F.532,AP.1,B.7,L.9.

${ }^{8} 1919$ m. birželio 17 d. prièmimo aktas,LVCA,F.532,AP.1,B.7,L.9.

${ }^{9} 1919$ m.liepos 3 d.prièmimo aktas, LCVA, F 532, AP. 1, B. 7, L. 7.
} 


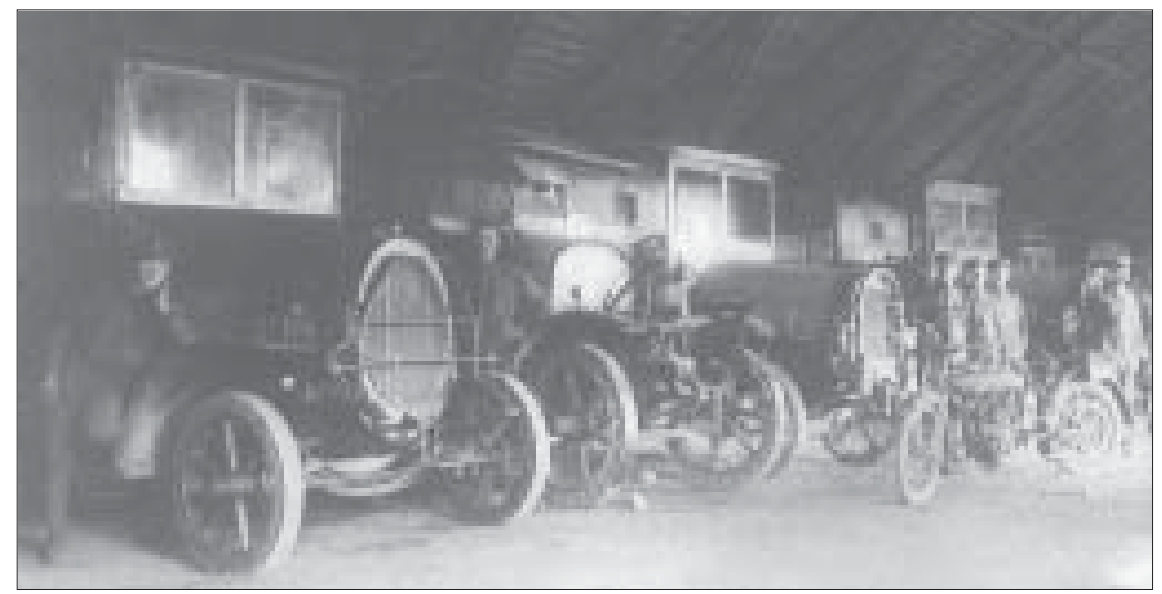

Pirmieji kariuomenès sunkvežimiai

Kariškių pastangos, padètos įsigyjant techniką, nenuėjo veltui. Jau 1919 m. vasarą kariuomenè turëjo 15 keleivinių ir 13 krovininių transporto priemonių, tarp kurių buvo 4 sanitariniai automobiliai ${ }^{10}$. Rudenį sanitariniam transportui skiriamas ir lengvasis automobilis, tačiau visiems automobiliams, kaip ataskaitoje nurode sanitarinio transporto vadas kapitonas I.Adamkavičius, reikèjo remonto ${ }^{11}$. Automobiliu batalione buvo 21 sunkvežimis, 13 lengvųjų automobilių, keturi sanitariniai sunkvežimiai "Ley" ir vienas šarvuotasis "FIAT" automobilis. Automobiliu kuopoje, kurios mokomajam būriui vadovavo jaunas leitenantas J. BarzdaBradauskas $^{12}$, buvo keletas mokomųu u "Opel" , "Benz", "Ford" markès lengvụjų automobilių bei "Ford", "Adler", "Fiat", "Komnick" markès sunkvežimių.

Daugejjant transporto, daugėjo ir kariškių, kurie ji galëjo valdyti. Kuopoje daugejjo ne tik karininkų, kareivių, bet ir laisvai samdomų vairuotojų. Jų buvo 14. Garažas automobilių kuopai paskirtas Donelaičio gatvejje, buvusioje cerkvejje ( vẻliau - senasis karo muziejus).Vyriausiojo karo vado generolo A.Žukausko 1919 m. birželio 20 d. įsakymu Nr.12 buvo nutarta automobilių komandą nuo birželio $7 \mathrm{~d}$. atskirti nuo auto-

\footnotetext{
${ }^{10}$ Karo dalių dvidešimtmetis 1919-1939 m. Kaunas.1939. P.129.

${ }^{11}$ LCVA, F 929, AP. 9,B.12, L. 56.

12 Tarnybos byla, LCVA,F.930,AP.5,B.213,L.8 a.p.
} 
mobilių kuopos ir priskirti "prie Generalinio Štabo Susisiekimo dalies. Viršiniku Auto komandos skiriu karininką Nivinskị, nuo š.m. birželio 7 d.” Šis padalinys su turimais automobiliais aptarnavo kariuomenès vadovus.

Automobilių priežiūrai ir remontui $1919 \mathrm{~m}$. spalio $22 \mathrm{~d}$. įsteigiamos automobilių dirbtuvės. Pirmuoju dirbtuvių vyriausiuoju mechaniku buvo paskirtas A.Sluckus. Dar vẻliau, 1922 m. balandžio 24 d., Centrinių kariuomenès dirbtuvių viršininku nuo kovo $22 \mathrm{~d}$. skiriamas majoras J.Leščiukaitis ${ }^{14}$.

1919 m. gruodžio mėnesį visi (lig tol išskirstyti) su transportu susieti junginiai sujungti ị vieną automobilių batalioną. Bataliono vadaviete ịsikūrẻ automobilių kuopos patalpose Kaune, Drobės gatvejje, o bataliono vadu paskirtas automobilių kuopos įkūrejas vyresnysis leitenantas S.Fanstelis ${ }^{15}$. Pasikeičia ir kariuomenès turimo transporto kiekis. Vien tik Inžinerijos dalyje sudarytame sąraše buvo šešiolika sunkvežimių, keturi sanitariniai automobiliai bei iš bolševikų paimtas šarvuotasis "Fiat" automobilis. Visas inžinerijos transportas nuo įsigijimo iki gruodžio $23 \mathrm{~d}$. sunaudojo 218 pūdų 20 svarų benzino, 20809 litrus benzolo ir 164 pūdus 31 svarą alyvos ${ }^{16}$.

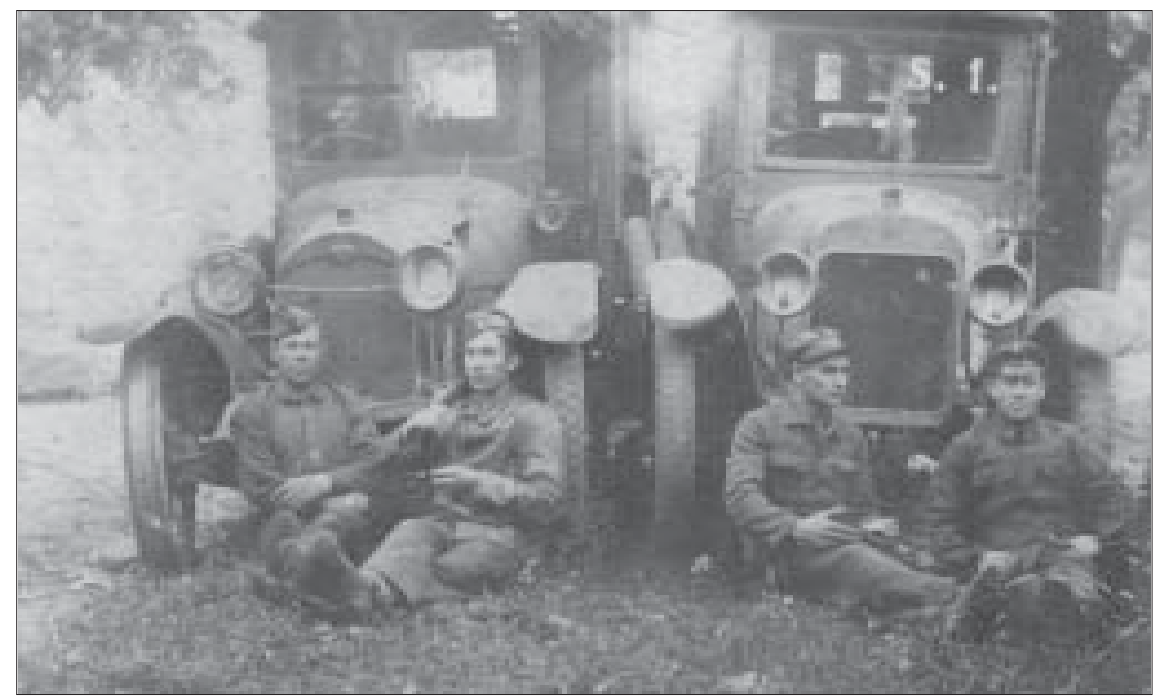

Pirmieji sanitariniai sunkvežimiai

\footnotetext{
${ }^{13}$ Vyriausiojo karo vado ịsakymas Nr.12, Kaunas, 1919 m. birželio 20 d.

${ }^{14}$ İsakymas kariuomenei, Nr.98, Kaunas, $1922 \mathrm{~m}$. balandžio $24 \mathrm{~d}$.

${ }^{15}$ İsakymas kariuomenei, Nr.200, Kaunas, 1919 m. gruodžio 7 d.

161919 m. gruodžio 23 d. sąrašas,LCVA, F. 929, AP. 9,B.12,L. 6-7.
} 
Kariuomenès vadovai sudare komisiją, kuri 1919 m. gruodžio 18 d. patikrino automobilių batalionui skirtus etatus ir pasiūle juos sumažinti daugiau kaip per pusę. Tam pritare kariuomenès vadas Pr. Liatukas ir buvo nuspręsta "laikinai laikyti pusę skaitliaus nurodytu etatuose kariškių"17. Ryškejjantys su kariuomenès vadovais nesutarimai dèl automobiliu batalionui skirtų etatų paskatino jo vadą S.Fanstelį rašyti pareiškimą susisiekimo dalies viršininkui, kuriame jis teige, kad "komisija juk nori pastatyt dalyką tiesiog kenksmingai, kaip jis nėra pastatytas nei vienoje Europos armijoje", o apkaltintas sabotažu paprašè "paliuosuoti nuo užimamos vietos" 18 .

Pirmojo automobiliu bataliono vado S.Fanstelio veikla kuriant Lietuvos kariuomenès automobilių transporto dalis būtų verta atskiro tyrimo, todèl pažvelgsime nors ị keletą jo tarnybos faktų, susijusių su automobiliu batalionu. $1920 \mathrm{~m}$. sausio $15 \mathrm{~d}$. automobilių bataliono vadas vyresnysis leitenantas S.Fanstelis patvirtino štabo karininkų, karo valdininkų ir kareivių pareigybes. Kapitonas K.Joniūnas buvo paskirtas adjutantu, laikinuoju automobiliu transporto kuopos viršininku - leitenantas A.Nasvytis, automobilių susisiekimo komandos viršininku - V.Nivinskas, automobilių sanitarijos transporto viršininku - kapitonas I.Adamkavičius, automobilių mokomosios komandos viršininku - J.Vyšniauskas, kartu jam pavesta laikinai eiti automobilių dirbtuvių viršininko pareigas ir t.t. ${ }^{19}$ Vyr. leitenantas S.Fanstelis automobiliu kuopai ir automobiliu batalionui vadovavo nuo $1919 \mathrm{~m}$. kovo $1 \mathrm{~d}$. iki $1920 \mathrm{~m}$. sausio $26 \mathrm{~d}$. I jo vietą vasario $20 \mathrm{~d}$. skiriamas kapitonas A.Daugirdas ${ }^{20}$, o vyresnysis leitenantas S.Fanstelis nuo $1920 \mathrm{~m}$. kovo 3 d. perkeliamas vadovauti automobilių dirbtuvių veiklai ${ }^{21}$. Visgi tarpusavio nesantaika netruko pasiekti apogèjų ir balandžio $20 \mathrm{~d}$. S.Fanstelis atsakydamas ị automobiliu bataliono vado A.Daugirdo ịsakymą parašè pareiškimą, kuriame išdèstė savo ketinimus. Jis pabrěžè, kad "tarnauti ne noriu ir ne galiu, priežastis silpnos sveikatos, nervas pratarnavus 6 metus visiškai sujudinti”22. Matyt, kad S.Fanstelio apsisprendimui daugiausia ịtakos turejjo aukštosios kariuomenès vadovybẻs požiūris i

\footnotetext{
17 Vyriausiojo kariuomenès vado $1919 \mathrm{~m}$. gruodžio 21 d.rezoliucija, LCVA, F.929,AP.9,B.12,L.21.

${ }^{18}$ S.Fanstilio pareiškimas, LCVA, F 929, AP. 9,B.12,L.

${ }^{19}$ LCVA, F 532, AP. 1, B. 8, L. 13-14.

${ }^{20}$ Tarnybos byla, LCVA,F.930,AP.2,B.179,L.32.

${ }^{21}$ LCVA, F. 532, AP.1, B.8, L.86 a.p.
} 
jo darbą, o ne paskirto naujo automobilių bataliono vadovo iniciatyvumas. Spalio $30 \mathrm{~d}$. kariuomenès vado įsakymu leitenantas S.Fanstelis buvo paaukštintas, nuo 1920 m. gegužès $1 \mathrm{~d}$. jam suteiktas kapitono laipsnis ${ }^{23}$. Manytina, kad tokio paaukštinimo be buvusio S.Fanstelio viršininko A.Daugirdo nebūtų buvę, nors tai buvo panašiau ị vẻluojančią moralinę satisfakciją.

1920 m. vasario 12 d. susisiekimo dalies viršininkas S.Fanstelis rašè, kad "kariuomenèje yra apie 170 automobilių"24. Sunkvežimiams, kaip ir kitoms technikos priemonėms, $1921 \mathrm{~m}$. buvo nustatyta ir patvirtinta benzino, tepalo normos, krovinių pervežimo kainos ${ }^{25}$. Dar kartą, jau kitos, kariuomenès transporto priemonių benzino, tepalo normos buvo patvirtintos $1928 \mathrm{~m}^{26}$

Vèliau kapitonui S.Fansteliui buvo patikèta ịkurti automobilių bataliono karo gaisrininkų tarnybą bei nuo $1921 \mathrm{~m}$. liepos 6 d. jai vadovauti. 1923 m. lapkričio mèn. kapitonas S.Fanstelis pasiprašè Lietuvos Respublikos Prezidentą atleidžiamas iš gaisrininkų tarnybos vado pareigų, ir jo noras gruodžio $9 \mathrm{~d}$. buvo patenkintas ${ }^{27}$. Kaip stropus karys jis buvo įvertintas dar 1920 m., kai buvo apdovanotas Vyčio kryžiumi su kardais, o atestacijos lape pažymėta, kad "naudingas kaipo energingas žmogus prie visokių sukilimų ir perversmų" 28 . Tokị įvertinimą jis užsitarnavo tuo, kad $1920 \mathrm{~m}$. vasario mènesį vykusio Kauno kareivių sukilimo metu drąsiai stojo ginti teisètą valstybès valdžią, panaudodamas jam patikètą techniką.

Kaip karo grobį inžinerijos kuopos kariškių komisijai 1920 m. sausio 3 d. Šiaulių stoties komendantas perdavè iš vokiečių paimtą sunkvežimị "Bergman-Metalurgique". Komisija, atidžiau apžiūréjusi trofẻjų, nustatė, kad sunkvežimis toks sudèvètas ir iškomplektuotas, jog jam būtinas kapitalinis remontas Centrinèse armijos dirbtuvėse ${ }^{29}$. Po kovų su lenkais buvo paimtas trofejjus - sunkvežimis "Benz", kuris po remonto pateko ị inžinerijos batalioną ${ }^{30}$.

\footnotetext{
${ }^{23}$ LCVA, F. 532, AP.1, B.8, L. 514 a.p.

${ }^{24} 1920$ m.vasario 12 raštas,LCVA,F.929,AP.9,B.12,L.22.

251921 m. spalio 24 d. aktas Nr.203,LCVA,F.1364,AP.1,B.208,L.4.

${ }^{26} 1928$ m. gegužès 8 d. aktas Nr.103,LCVA,F.1364,AP.1,B.208,L.5-6.

27 Tarnybos byla,LCVA, F 930, AP.2, b.2, L.17.

${ }^{28}$ Tarnybos byla, LCVA, F 930, AP.2, b.2, L.22.

${ }^{29} 1920$ m. sausio 3 d. priëmimo aktas, LCVA, F 1, AP. 1, B. 121, L. 6.

${ }^{30}$ 1920m.lapkričio 16 d. komisijos prièmimo aktas,LCVA,F.1,AP.1,B.121,L.42. 
1920 m. kovo 6 d. kariuomenès automobilių technikos ūki papildè dar 22 ịvairių markių sunkvežimiai bei vienas lengvasis "Adler" markès automobilis ${ }^{31}$. Šie automobiliai Lietuvos kariuomenei atiteko kaip ir kovo $17 \mathrm{~d}$. gauti du lengvieji "Hansa - Loyd" bei du "Brennabor" automobiliai, generolo H.A.Niselio vadovaujamos santarvininkų komisijos sprendimu $^{32} .1920 \mathrm{~m}$. rugsẻjo ménesį automobilių kuopa, išlaikydama savo pavadinimą, liko kaip atskiras vienetas, tačiau joje atsirado naujų junginių: automobilių komanda, sanitarijos automobilių transportas bei šarvuotų automobilių būrys. Pasikeitè ir automobilių kuopos dislokacijos vieta. Automobilių kuopai atiteko buvusio rusų pontonų bataliono kareivinès Šančiuose. Paskirtos kareiviniu patalpos buvo "labai netvarkoje - pečiai neuždaromi, langai vieni ir tie kiauri, kad stačiai po butus vaikščioja vejjas" 33, sugriautomis krosnimis, o automobiliams skirtas garažas buvo be lubų.

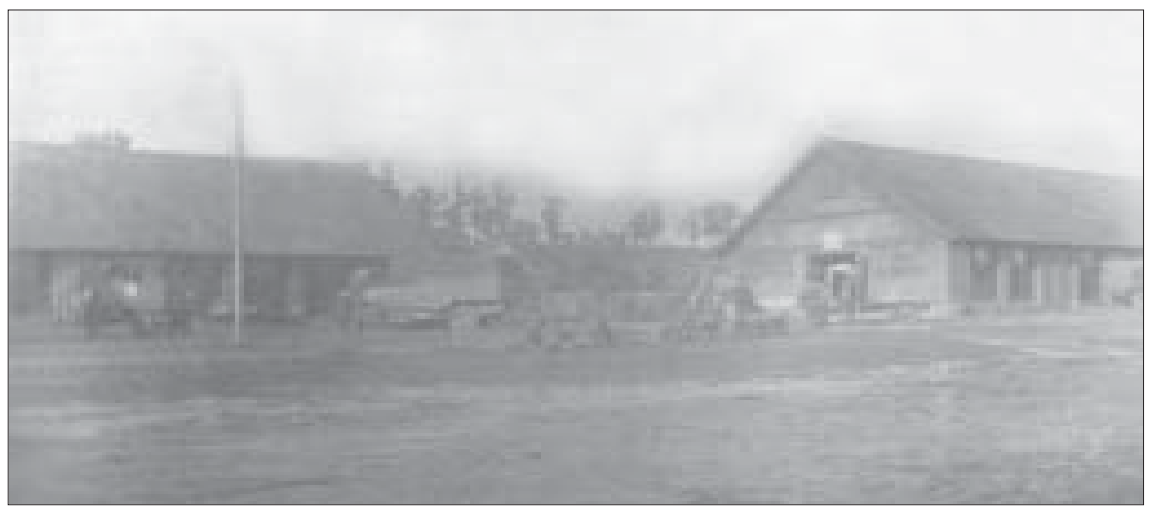

Kariuomenès automobilių kuopos garažai Šančiuose

1920 metų pabaigoje automobilių batalioną sudarè daugiau kaip šimtas automobilių ir motociklų. Automobilių batalione esančios transporto priemonès buvo pirktos, išmainytos, surinktos ir sutaisytos iš paliktų pasitraukiančios vokiečių kariuomenès, todèl čia buvo galima pamatyti ivvairiausių markių ir modelių automobilius. Lietuvos kariuomenė turejjo

311920 m. kovo 6 d. priemimo aktas Nr.39/92,LCVA, F 1, AP. 1, B. 121, L. 8.

32 Sąrašas, LCVA, F 929, AP. 9,B.12,L. 93.

${ }_{33} 1920$ m. sausio 13 d. pranešimas, LCVA, F 929, AP. 9,B.12,L.11. 
ne tik vokiečių mituose minimos mergelès - undinès "Loreley" - vardu pavadintą sunkvežimi, bet ir automobilizmo pradininko kūrinị - "Benz" - bei “Opel”, “Arbenz”, “N.A.G.”, "Hanza”, “Adler”, "Komnick” ir t.t. Likvidavus Lietuvoje plk. Bermonto-Avalovo karinius junginius, kariuomenès ūkis pasipildè dar pusšimčiu senų krovininių “Adler”, "Horch", "Packard”,"Dodge", "Diürkopp", “Albion”, "Liberty” ir kt. sunkvežimių bei daugiau kaip dvidešimčia ịvairiausių markių lengvụjų automobilių ${ }^{34}$. Kariuomenès sanitarijos tarnyba naudojo vienuolika “Audi", "Ley”, “Benz", o nuo 1925 m. ir "Berliet” markès sanitarinių automobilių. Visus juos reikèjo daugiau ar mažiau remontuoti.

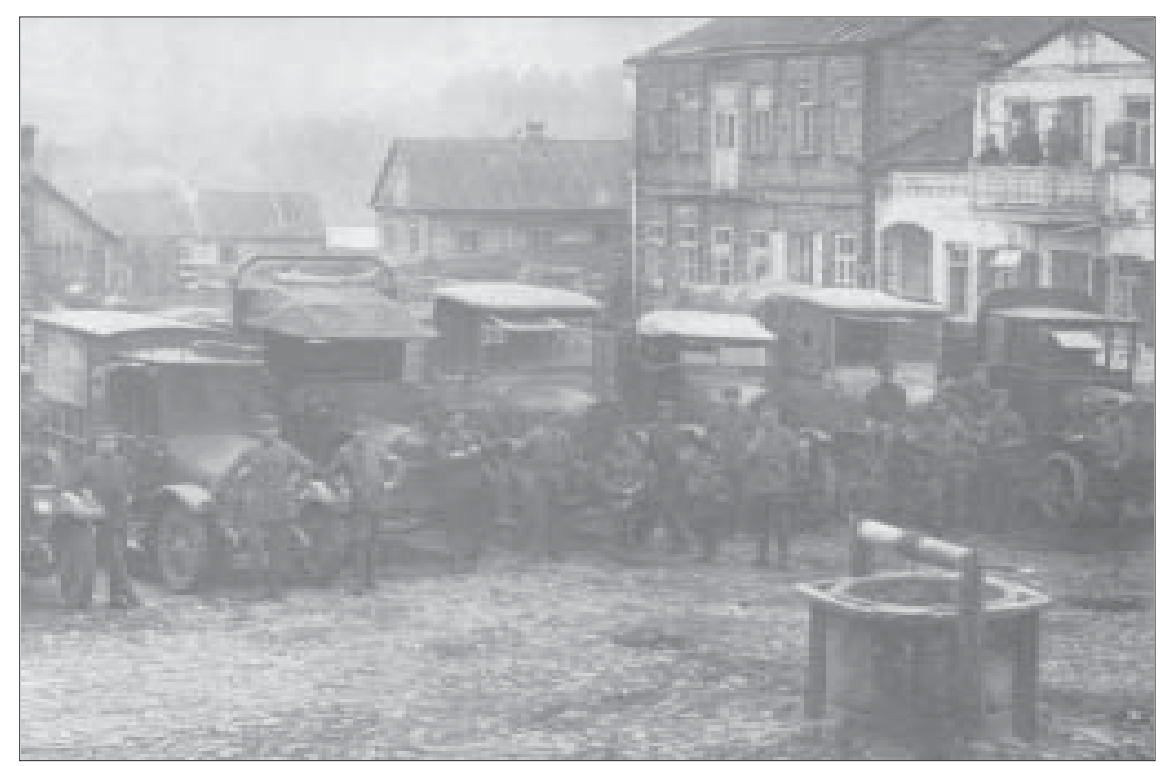

Automobilių kuopos sunkvežimiai

Pirmieji Lietuvos kariuomenès įsigyti sunkvežimiai buvo pasenusios konstrukcijos, sukamasis judesys buvo perduodamas grandine, o ir benzino, palyginti su trečiojo dešimtmečio technika, ėmè labai daug. Ypač tai pasakytina apie sunkvežimi "Benz", kuris 100 km su-

${ }^{34} 1920$ m.vasario 14 d. komisijos priėmimo aktas,LCVA,F.929,AP.3,B.140, L.48 
naudodavo 151 litrą benzino ir 10,1 litro tepalo, bei "Arbenz", kuris $100 \mathrm{~km}$ sunaudodavo 102,5 litro benzino ir 7,5 litro tepalo. Sunkvežimiai buvo su metaliniais ratlankiais, ant kurių buvo pritvirtinamos kietos gumos padangos. Dẻl netobulos važiuoklès sunkvežimiai galèjo važinèti tik keliais su tvirta danga, be to, jie sukeldavo daug rūpesčių vairuotojams nuo lietaus pažliugusiuose vieškeliuose, lauko keliuose.

Daugëjant kariuomenėje karininkų, kareivių ir technikos, buvo būtina mokyti šauktinius vairuoti ir aptarnauti kariuomenès transporto priemones. $1920 \mathrm{~m}$. spalio $20 \mathrm{~d}$. pradejo veikti mokomoji komanda (karinių vairuotojų mokykla). Automobilių kuopos mokomajame būryje buvo mokoma dviem etapais. Mokant karius vairuoti karinius automobilius, daugiausia laiko buvo skiriama dviem dalykams: pirma praktiniams darbams dirbtuvėse, garaže, juos supažindinant su automobilio sandara, ir antra - formuoti vairavimo igūdžiams. Visiems kitiems mokymo proceso uždaviniams - susipažinti su elektros įrengimais, naudojamomis medžiagomis, fizikos, chemijos, geometrijos, topografijos pradmenimis ir vairavimo teorija - laiko buvo skirta daug mažiau $^{35}$. Automobilių kuopos mokomajame būryje buvo rengiami ir motociklininkai, nes kariuomenėje šauktiniams tekdavo vairuoti ir motociklus. Pirmasis mokomosios komandos viršininkas buvo inžinierius vyresnysis leitenantas J.Grinkevičius. Automobilių batalione buvo 21 sunkvežimis, 13 lengvųjų, keturi sanitariniai "Ley" ir vienas šarvuotasis "Fiat" automobilis.

Mokymo procesui spartinti ir igūdžiams formuoti buvo pagamintas ir naudojamas važiavimo veiksmų treniruoklis - "trenažierius". Jame buvo visi automobilio valdymo ịtaisai: vairas, stabdžiai, sankaba, akceleratorius, greičių perjungimo svirtis. Mokymo vietų treniruoklyje buvo aštuonios, o kursantai, pramokę "važiuoti" treniruokliu, instruktoriaus vadovaujami galẻdavo pavažiuoti pirmuosius kilometrus sunkvežimiu bei lengvuoju automobiliu. Mokomajai kuopai vadovavo leitenantas J.Barzda-Bradauskas, kuris po kelerių metų siunčiamas mokytis ị Prancūziją. Automobilių kuopos mokomajame būryje buvo keletas mokomujų "Opel”, "Benz", "Ford" markès lengvųjų automobilių bei "Ford”, "Adler", "Fiat”, "Komnick”, “Arbenz", "Albion” markès sunkvežimių.

351922 m. balandžio 21 d. posèdžio Nr.20 protokolas,LCVA,F.1364,AP.1,B.13,L.23A.P. 


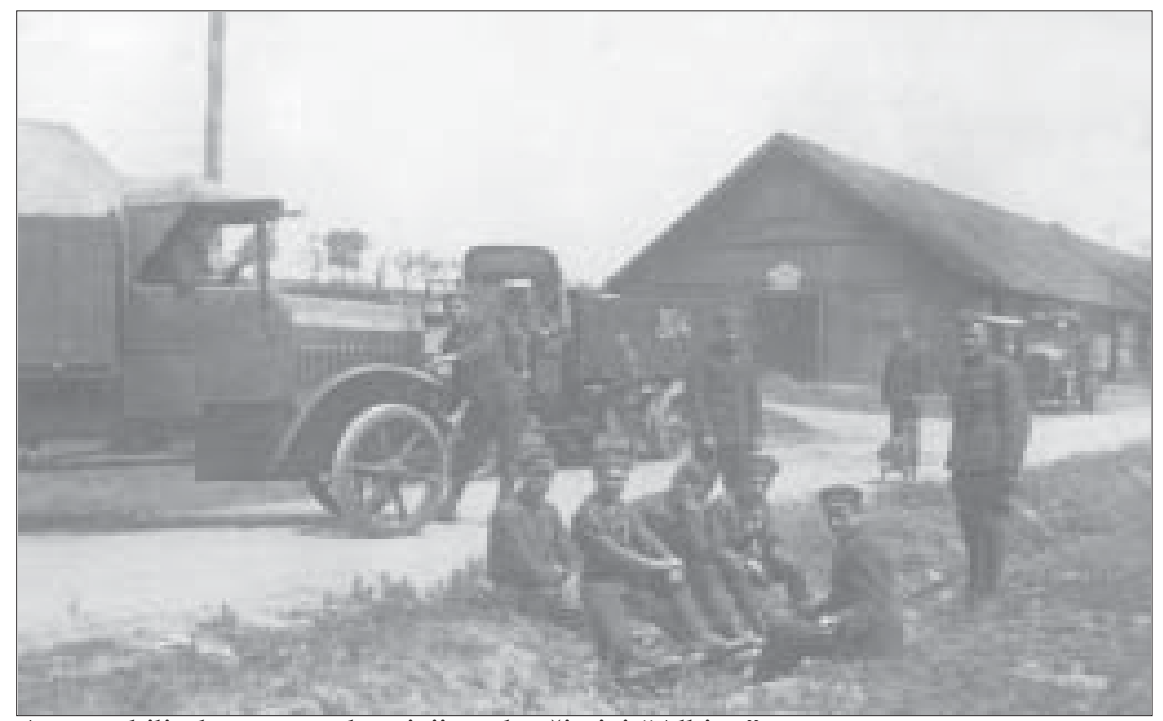

Automobilių kuopos mokomieji sunkvežimiai “Albion”

1921 d. birželio 14 d. įsakyme kariuomenei visų dalių vadams ir i̊staigų viršininkams buvo nurodyta "visus esančius jų žinioje šoferius ir motociklistus, tarnaujančius ne su lig savo specialybės, prisiųsti ant š.m. birželio 25 dienos i Auto-batalioną padarymui jiems kvotimų"36.

Lietuva, negaledama gaminti transporto priemonių savo šalyje, naujus automobilius ir jų dalis turejo pirkti užsienyje. Tiesa, naują sunkiąą transporto techniką kariuomenè įsigyti pajėgè tik sustiprẻjus valstybès ekonomikai. 1929 m. kariuomenei buvo nupirktos net 24 naujos "Fiat 507 F-A" važiuoklès, krovininiai kẻbulai bei kabinos toliau gaminamos vietoje $^{37}$. Pirmajị valstybingumo dešimtmetị kariuomenès transportas savo ịvairove buvo panašus ị skubiai ịsteigtą technikos muziejų ir sunkiai tenkino reguliariosios kariuomenès poreikius.

Kaip vieną iš reikšmingesnių veiksmų, kuriais karinių operacijų metu pasižymėjo automobilių batalionui priklausantis 1 péstininkų divizijos automobilių būrys, reikètų priminti kautynes su lenkais ties Širvintomis. Šis būrys su aštuoniolika sunkvežimių, lenkų kariuomenei puolant Širvintas, skubiai evakavo intendantūros sandèlius bei

\footnotetext{
${ }^{36}$ İsakymas kariuomenei Nr.135, Kaunas,1921 m. birželio $14 \mathrm{~d}$.

${ }^{37} 1929$ m. gegužès 4 d. priëmimo aktas,LCVA,F.1364,AP.3,B.14,L.230.
} 


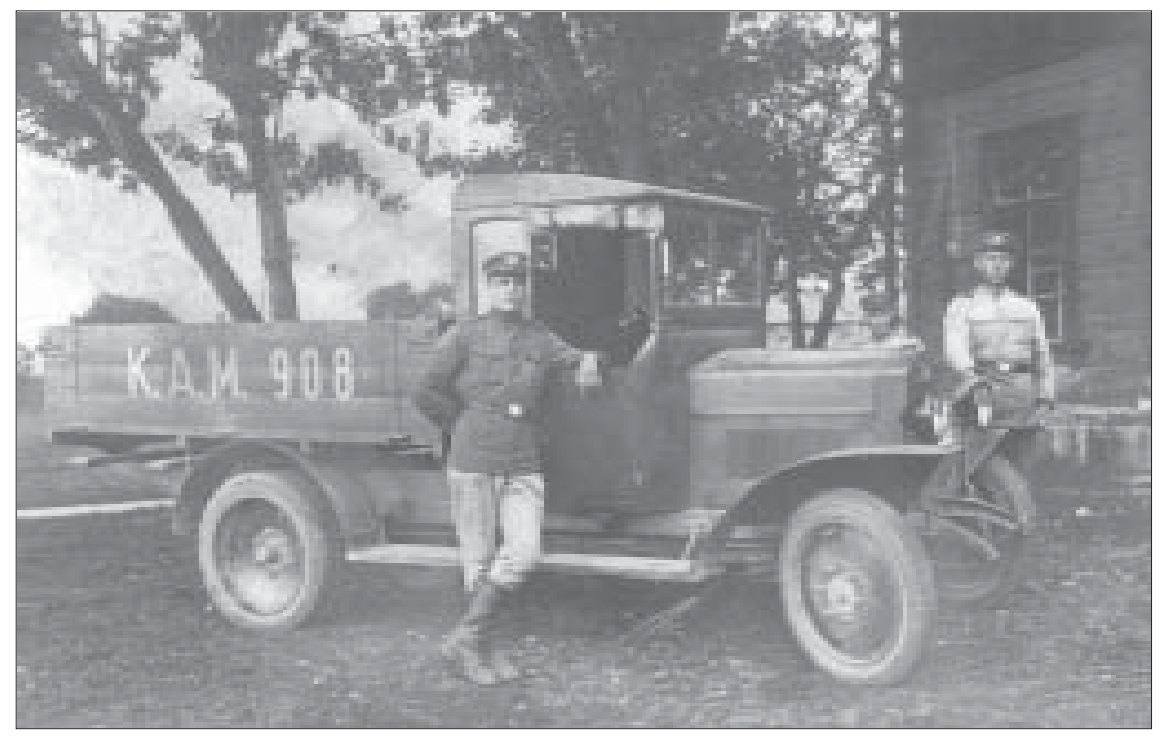

Kariuomenès sunkvežimis "Fiat"

išgelbėjo šiose kautynèse sužeistus karius - pervežè juos ị ligonines. Šioje akcijoje dalyvavo aštuoniolika krovininių sunkvežimių, du sanitariniai automobiliai ir keturi motociklai. Tai buvo bene pirmas kartas, kai Lietuvos kariuomenejje buvo panaudota daugiau automobilių. Parengtame sukilimo Klaipėdoje plane buvo numatyta, kad minėtoje karinejje operacijoje bus panaudoti devyni automobilių bataliono kareiviai su jiems priskirtais sunkvežimiais. Sukilimas buvo sėkmingas, tad dalis šios sėkmès priklausė ir nuo operatyvaus transporto technikos panaudojimo ${ }^{38}$.

Karo technikos viršininko pulkininko Kurkausko 1922 m. lapkričio 28 d. sprendimu sudaryta komisija gavo užduotị susipažinti su lengvųjų automobilių transporto būkle ir pateikti siūlymus dẻl būklès gerinimo bei kaip elgtis kariuomenei su netinkamomis transporto priemonėmis. Po keleto posėdžių komisija konstatavo, kad kai kurių automobilių eksploatacija tris kartus viršijo jų įsigijimo kainą ir pasiūlè visus automobilius suskirstyti į tris rūšis: “1) pilnai tinkančios karo tikslams prie visokių ap-

38 A. Gaigalaite Ernesto Galvanausko politinè veikla dèl Klaipėdos krašto prijungimo prie Lietuvos. Lietuvos istorijos metraštis. 1996 metai.Vilnius, 1997 m. psl.147. 
linkybių; 2) tinkamos dèl gerų kelių, plentų ir nedidelių atstumų; 3 ) visai netinkamos". Dešimti automobilių, kuriuos priskyrė trečiajai grupei, buvo pasiūlyta išbraukti iš autobataliono turto sąrašų kaip nuostolingus eksploatuoti $^{39}$. Plk. Kurkauskas, motyvuodamas, kad kai kurie komisijos siūlymai viršijo karo technikos viršininko galimybes igyvendinti siūlymus, kreipèsi i krašto apsaugos ministrą majorą B. Šližį ir prašė patvirtinti komisijos parengtą aktą. Karo technikos viršininkas suabejojo komisijos pasiūlyta neliečiamosios automobilių atsargos sudarymo idejja, nes manè, jog "artimiausioj ateity šito negalima bus ịgyvendinti”, bei vylèsi, "kad karui ištikus lengvaji transportą galima bus papildyti rekvizuotomis (transporto priemonėmis -V.G.) iš civilių asmenų"40. Toks požiūris rodè, jog kariuomenès technikos vadovas neįvertino ir nesuprato automobilių transporto svarbos kariuomenès mobilumui ir veiklos efektyvumui. Beveik toks pat požiūris vyravo ne tik žvelgiant ị kariuomenès lengvajị, bet ir sunkujji transportą.

1923 m. vasario 23 d. šalies ministrų kabinetas, apsvarstęs ekonominę padėtị, prekių ịsigijimą užsienyje, pareiškè, kad valdžios ịstaigos susilaikytų prekes pirkusios užsienyje, kad jas turètų pirkti savo šalyje, nors tektų mokèti brangiau, taip pat kad nepirktų tų prekių, be kurių galima išsiversti arba kurias galima nusipirkti vẻliau. Ministrų kabineto sprendimą krašto apsaugos ministras majoras B.Sližys paskelbė kariuomenès vadovybei. Dažnai pasitaikydavo, kad atskirų kariuomenès rūšiu daliniai pirkdavo mažai arba per daug. Todèl $1922 \mathrm{~m}$. balandžio 4 d. įsakymu buvo nustatyta, kaip kariuomenès dalys turètų pirkti centralizuotai ir vienodos rūšies medžiagas. Naujus automobilius, motociklus ir dviračius bei šaltkalvių ịrankius centralizuotai pirkti ịpareigojamas Karo technikos tiekimo skyrius ${ }^{41}$.

I 1926 metus Lietuvos kariuomenè izžengė turẻdama 31 lengvaji automobilį, 73 sunkvežimius, 16 sanitarinių automobilių bei 68 (kovo mèn. duomenimis) motociklus ${ }^{42}$. Dalis pasenusios technikos buvo parduota iš varžytinių ${ }^{43}$. Vyriausiojo štabo sprendimu nuo sausio $1 \mathrm{~d}$. automobilių

\footnotetext{
391923 m.sausio 17 d.aktas Nr.9, LCVA,F.1364,AP.1,B.68,L.12-13.

401923 m.sausio 30d. karo technikos viršininko raportas, LCVA,F.1368,AP.1,B.68,L.15.

${ }^{41}$ İsakymas kariuomenei Nr.91, Kaunas, 1923 m. gegužès 15 d.

${ }^{42}$ LCVA, F.532, AP. 1, B. 35, L. 24-28.

${ }^{43} 1925$ m. liepos 8 d. technikos ịkainavimo aktas, LCVA, F.532, AP. 1, B. 35, L. 18. 
batalionas buvo išformuotas, kaip ir inžinerijos pulkas, elektrotechnikos, geležinkelio batalionai. Pagrindinè mintis, gimusi kariuomenès strategu galvose, buvo ta, kad norèta visas kariuomenès technikos rūšis sujungti ị vieną technikos pulką, tikintis geresnio valdymo ir lèšų ${ }^{44}$. Automobilių bataliono karininkai vadai išskirstomi po įvairias kariuomenès dalis - technikos pulką, šarvuočių rinktinę, štabo susisiekimo skyrių, aviaciją, intendantūrą ${ }^{45}$. Matyt, kariuomenès pertvarkymams turèjo ịtakos ne tik naujos koalicinès vyriausybės apsisprendimas, bet ir nerimą Lietuvos valstybei kelianti kaimyninès Lenkijos politika.

Tokia struktūra išsilaikè tik 1927 m., o tų pačių metų rugpjūčio mènesi technikos pulkas buvo išformuotas, jo vadas pulkininkas leitenantas K.Voicechauskas atleistas, ir vèl viskas grịžo ị ankstesnes vėžes. Technikos pulkas nepateisino i jị dètų vilčių, nes tai buvo dirbtinai sudarytas įvairių specialybių ir kariuomenès techniškujjų tarnybų junginys. Matyt, kad nemažą ịtaką tokiam kariuomenès vadovų apsisprendimui turejo išryškėjęs kariškių nepasitenkinimas ịvykusiais pasikeitimais. Automobilių dalis vèl tapo atskiru vienetu - automobilių kuopa, o jai vadovauti paskiriamas majoras V.Aužbikavičius ${ }^{46}$.

1927 m. spalio 13 d. Vyriausiojo štabo įsakymu buvo sudaryta komisija. Jos pirmininkas buvo Karo technikos viršininkas pulkininkas St.Dirmantas, o nariai - Centrinių kariuomenès dirbtuvių viršininkas inžinierius N.Dobkevičius, Aukštųjų karininkų kursų lektorius inžinierius M.Piskorskis, Karo technikos tiekimo skyriaus viršininkas pulkininkas leitenantas K.Joniūnas, Karo technikos štabo majoras J. Barzda-Bradauskas ir automobilių kuopos vadas majoras V.Aužbikavičius. Komisijos svarstè, kokie lengvụjų automobilių ir sunkvežimių tipai būtų tinkamiausi kariuomenei, atsižvelgiant ị šalies klimato sąlygas.

Krovininiai automobiliai, kuriuos norejo įsigyti kariuomenè, buvo pageidautini dviejų tipų: $1,5-2$ tonų ir 2,5 - 3 tonų keliamosios galios. Komisijos nariai pažymėjo, kad parinkti automobilio firmą ir modeli galima tik perkant konkrečius automobilius, nes gamyba plečiasi ir automobilių modeliai greitai keičiasi. Jie taip pat konstatavo, kad sunku tikėtis, nors šalies geografinè padėtis ir patogi, jog kuri nors automobilių firma

\footnotetext{
${ }^{44}$ Isakymas krašto apsaugos ministerijai Nr.3, Kaunas, 1926 m. sausio 6 d.

${ }^{45}$ Krašto apsaugos ministro įsakymas Nr.4,Kaunas, 1926 m.sausio 6 d.

${ }^{46}$ İsakymas kariuomenei Nr104, Kaunas, 1927 m. rugpjūčio 29 d.
} 
sutiks steigti Lietuvoje automobilių surinkimo gamyklą. Todèl norint skatinti sunkvežimių, kurie karo metu galètų būti pritaikyti kariuomenès reikalams, įvežimą, reikia perkantiesiems tokio tipo sunkvežimius teikti nuolaidas, mažinti muitus ir mokesčius už šių automobilių eksploatavimą ${ }^{47}$.

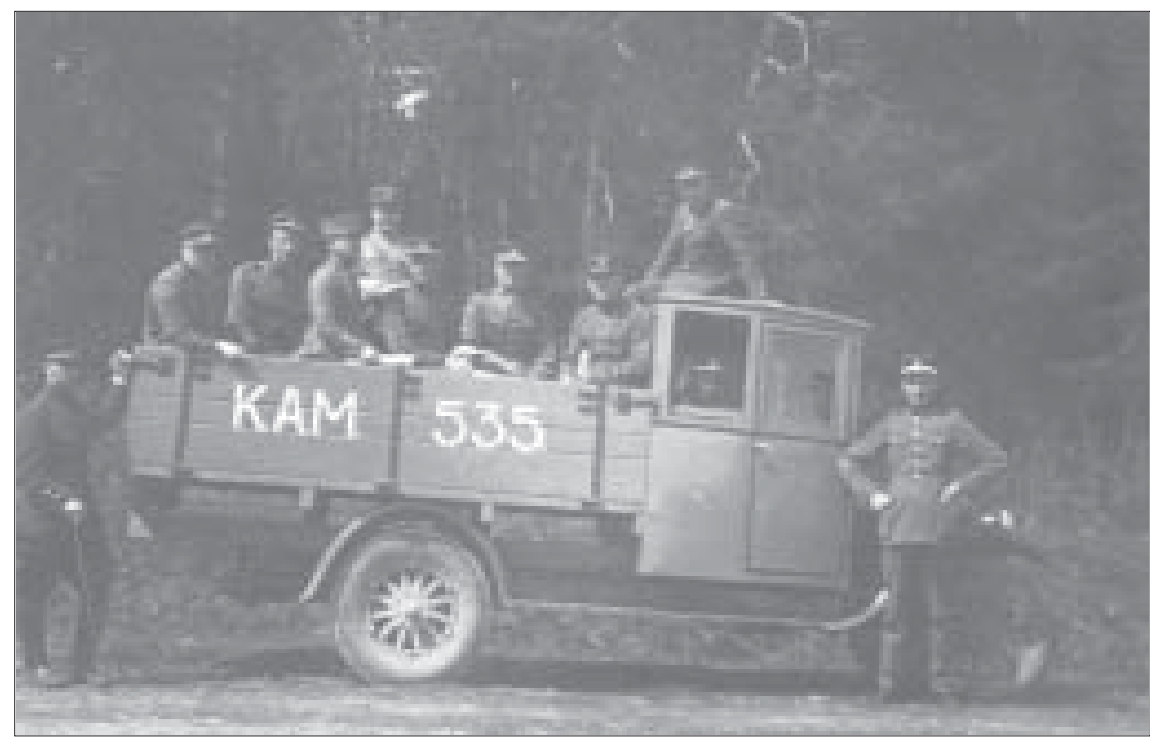

Sunkvežimiai tobulèja

1928 m. rugsèjo 13 d. Karo technikos tiekimo užsakymų skyrius kreipèsi i savo viršininką. Slaptame rašte buvo pažymèta, kad iki tol visi skyriaus pirkimai vyko be jokių direktyvų iš vyriausiojo štabo pusės ir prekès buvo perkamos iš tarpininkų, kurie siūlè mažiausią kainą, retai atsižvelgiant i jų kokybę. Kaip pažymėjo raporto autorius, tokią situaciją lẻmé tai, kad Lietuvoje vis dar veikè carinès Rusijos civiliniai ịstatymai, leidžiantys tiekime dalyvauti ir užsienio tarpininkams, pvz., perkant naftą lenkų tiekẻjai kainos požiūriu sẻkmingai sugebẻjo nukonkuruoti pasaulines naftos produktų firmas "Standart Oil Co" ir "Shell Co". Tarpininkų dalyvavimas tiekiant karo techniką buvo palaikytas nepatikimu ir nepageidaujamu, argumentuojant tuo, kad prasidejus karui tarpininkai

${ }^{47}$ LCVA, F 1364, AP.1, B. 279, L. 9 - 10. 
dings, nutrauks prekybinius ryšius, o jų kainos net ir po konkurencinès kovos visada bus didesnès už firmų, kurios norètų turèti daugiamečius kontraktus $^{48}$.

Karinès transporto priemonès turèjo savą numerių suteikimo sistemą $^{49} .1927$ m. Krašto apsaugos ministerijai parengus transporto registravimo ženklus, gruodžio mėnesi jie buvo patvirtinti, o $1928 \mathrm{~m}$. paskelbus îsakymą kariuomenei Nr.39 dèl automobilių transporto ženklinimo - įsigaliojo.Visoms kariuomenès transporto rūšims: lengviesiems, sanitarijos, krovininiams automobiliams bei motociklams buvo nustatytos žymejjimo ir numeravimo taisyklès. Sunkvežimių kẻbulų šonuose ir galuose turẻjo būti baltais dažais rašomos raidès K.A.M. ir skaičius. Tokia transporto registracija galiojo Aukštųju karininkų Didžiojo Lietuvos kunigaikščio Vytauto kursų, Aviacijos štabo ir parko, Šaulių sajungos, Centrinių kariuomenès dirbtuvių, Śarvuočių rinktinès, Automobilių kuopos automobiliams $^{50}$. Sanitariniai automobiliai (vairuotojo kabina bei galinès kébulo durys) buvo žymimi raudonu kryžiumi baltame apskritime. Sanitariniai automobiliai priekyje turèjo trikampę numerio lentelę, kẻbulo šonuose už apskritimo buvo rašomos raidès K.A.M. ir skaičius, gale - tokios pat formos ir dydžio užrašai kaip ir sunkvežimių. Vèlesniais metais, be užrašu sunkvežimių šonuose ir gale, papildomai buvo privaloma turèti priekyje - baltos spalvos lygiakraščio trikampio formos sunkvežimio registracijos lentelę su arabiškais skaitmenimis užrašytu numeriu, galinėje transporto priemonès dalyje - ovalo formos baltą lentelę su inicialais K.A.M. ir numeriu. Sunkvežimių numeriai buvo ne tik triženkliai, bet ir keturženkliai. Visiems kariuomenès automobiliams ir motociklams numerius skyre Karo technikos tiekimo skyrius. Tiesa, Krašto apsaugos ministerijai pageidaujant, kai kurie automobiliai, kaip ir kiti civilinių įstaigų tarnybiniai automobiliai, galëjo būti registruoti bendra tvarka ${ }^{51}$.

$1930 \mathrm{~m}$. sausio $1 \mathrm{~d}$. krašto apsaugos ministras pulkininkas leitenantas J.Variakojis patvirtino "Instrukciją auto priemonių tarnybai". Minètoje instrukcijoje buvo reglamentuotas kariuomenès automobilių tarnybos funkcionavimas, nustatytas transporto suskirstymas pagal transporto priemonių tipus, tarnybos valdymas, transporto rūšiavimas vykdant techni-

${ }^{48}$ LCVA, F.532, AP. 1, B. 192, L. 38-39.

${ }^{49}$ Judejimo tvarkos taisyklès, Kaunas, 1940m.,psl.6.

${ }^{50}$ LCVA, F 1364, AP.1, B. 166, L. 265 - 266.

${ }^{51}$ Vyriausybès Žinios, 1936 m. rugsèjo 2 d., Nr.548, eil. 3817. 
nę priežiūrą, transporto priemonių atsargų sudarymas ir kt. Pagal šią instrukciją visos kariuomenès transporto priemonès buvo suskirstytos i penkias grupes: keleivinius automobilius ir motociklus, lengvuosius sunkvežimius (nuo 1 iki 2 tonų keliamosios galios), sunkiuosius sunkvežimius (daugiau kaip 2 tonų keliamosios galios), traktorius ir sanitarinius automobilius. Kariuomenès automobilių transporto tarnybai vadovavo viršininkas. Šias pareigas ejjo automobilių kuopos vadas, tiesiogiai pavaldus Karo technikos viršininkui. Automobilių kuopos vadas be tiesioginio vadovavimo kuopai buvo atsakingas už visų autotransporto priemonių (nesvarbu, kam jos priklausytų) tinkamą priežiūrą ir kontrolę, privalëjo užtikrinti automobilių tarnybai reikalingų išteklių kiekị, pasirūpinti jų užsakymu bei aptarnauti su jomis kariuomenès štabus, dalis ir įstaigas. Ši instrukcija numatè, kad tiek asmeninio, tiek ir bendrojo naudojimo automobiliams nustatomos benzino ir tepalų normos, kiekvienam viršininkui ar įstaigai ịvedama kuro, tepalų naudojimo norma bei asmeninė kuro, tepalų naudojimo apskaita ${ }^{52}$. Paskelbiamos bendrosios metinès sunkvežimių, sanitarinių automobilių, motociklų ir dirbtuvių eksploatacijai bei mokymo reikmėms reikalingos benzino normos, kurios sudare daugiau kaip 54 tūkst. $\mathrm{kg}^{53}$.

Kiekvienų metų gegužès mėnesio pirmoje pusėje Karo technikos viršininkas sudarydavo komisiją, kuri privalejjo patikrinti visas kariuomenės transporto priemones ir pagal techninę būklę suskirstyti ị tris rūšis. Pirmai rūšiai priklausẻ visiškai tvarkingos ir tinkamos tolimai kelionei transporto priemonès, antrai - tvarkingos, bet netinkamos ilgesnei kaip $120 \mathrm{~km}$ kelionei bei trečiai - dèl gedimų negalinčios važiuoti, tačiau po remonto panaudotinos mokymo tikslams. Vyriausiojo štabo viršininkui patvirtinus automobilių transporto priemonių peržiūrèjimo aktą, Karo technikos tiekimo skyriaus viršininkas įvertintas ir pripažintas netinkamomis naudoti transporto priemones galèjo palikti mokomajam būriui kaip modelius, išardyti arba sudaryti komisiją, kuri jas įkainotų ir parduotų iš varžytinių.

1930 m. gegužès 27 d. Karo technikos viršininko įsakymu buvo sudaryta komisija, kuriai vadovavo Vytauto Didžiojo karininkų kursų inžinierius M. Piskorskis, o jos nariai buvo automobilių kuopos vadas majo-

\footnotetext{
${ }^{52}$ Instrukcija auto priemonių tarnybai, Vyr. štabo sp. ir švt. sk. leidinys, Kaunas, $1930 \mathrm{~m}$.

${ }^{53}$ İsakymai kariuomenei Nr.38, Kaunas, 1930 m. rugpjūčio 6 d.
} 
ras V. Aužbikavičius, Karo technikos tiekimo skyriaus kapitonas C. Kazakevičius, Šarvuočių rinktinès atstovas kapitonas Urbanas, 1-osios oro eskadrilès atstovas kapitonas Gricevičius. Komisija turèjo peržiūrèti visas transporto priemones, ịvertinti jų techninę būklę bei nurodyti laiką, per kuri jas galima suremontuoti. Iš ataskaitos matyti, kad 1930 m. kariuomenèje daugiausia buvo 1927-1928 m. gamybos transporto priemonių. Tarp jų daugiausiai "Ford" markès lengvụjų automobilių, keletas "Benz", "Fiat", "Studebaker", "Buick”, “Adler", “ Opel”, "Fiat” automobilių".

Lietuvos kariuomenèje 1934 m. birželio 1 d. karo technikos viršininko įsakymu sudaryta komisija sugrupavo ir pateikẻ kariuomenés autotransporto priemonių suskirstymo ị rūšis aktą. Tuo metu kariuomenèje buvo 206 automobiliai ir motociklai ${ }^{55}$.

Ketvirtojo dešimtmečio antrojoje pusèje, kariuomenès vadu paskyrus pulkininką St.Raštikị, kariuomenei pasitaike gera proga papildyti savo technikos ūki naujais sunkvežimiais. 1935 m. pirmajame Valstybės gynimo posėdyje buvo svarstomas pulkininko S.Raštikio pateiktas kariuomenès pertvarkymo planas, kuris numate, kad per ateinančius septynerius metus kasmet kariuomenei būtų skiriama po 25 milijonus litų. Tai buvo didelis pasiekimas, nes tik turint lèšų buvo galima pradėti techninị kariuomenės pertvarkymą. Matyt, didžiausią įtaką prezidentui A.Smetonai priimant ši sprendimą turèjo pulkininkas S.Raštikis $^{56}$. Padidinus kariuomenès biudžetą buvo numatytos lèšos naujai technikai ịsigyti. $1934 \mathrm{~m}$. kariuomenei buvo skirta 10,21 mln. Lt nepaprastụjų išlaidų, $1935 \mathrm{~m}$. skiriama 19,68 mln. Lt, o $1936 \mathrm{~m}$. - net 25,00 mln. Lt. Sunkvežimiai buvo perkami ir už visuomenès paaukotas lèšas.Už Ginklų fondo surinktas lèšas Pirmoji šaulių rinktinè norejjo įsigyti 8 sunkvežimius, todėl Kauno komendantas J.Bobelis, norėdamas pasitarti, kreipèsi į karo technikos tiekimo viršininką ${ }^{57}$. Atsakymas buvo trumpas ir aiškus: pirkti dviašius 1,5-2,5 t krovos sunkvežimius, kurių kaina - 8000 Lt.

Vien tik $1936 \mathrm{~m}$. kariuomenès automobilių rinktinèje buvo naudojami septyni "Fiat", penki "Morris Commercial", po vieną "Arbenz" ir

\footnotetext{
${ }^{54}$ LCVA, F 1364, AP.1, B. 243, L. 58-63.

${ }_{55}$ LCVA, F. 532, AP. 1, B. 102, L. 70-76.

${ }^{56}$ A.Šliogeris, Antanas Smetona. Žmogus ir valstybininkas.Cleveland, 1966 m., psl. 133.

${ }^{57}$ Kauno komendanto 1939 m. birželio 16 d. raštas Nr.6024, LCVA, F 1364, AP.3, B. 525, L. 319.
} 
"Horch", du "Chevrolet". Kai kurie sunkvežimiai buvo naudojami tik kaip mokomieji: po vieną "Fiat", "Büssing", "NAG", "Arbenz", trys "Komnick" bei kiti atsargoje laikomi: penkiolika senų "Komnick" ir po vieną "Leyland", "Pacckard", "Benz", "Liberty", "Daag", "NAG", "Adler" 58 .

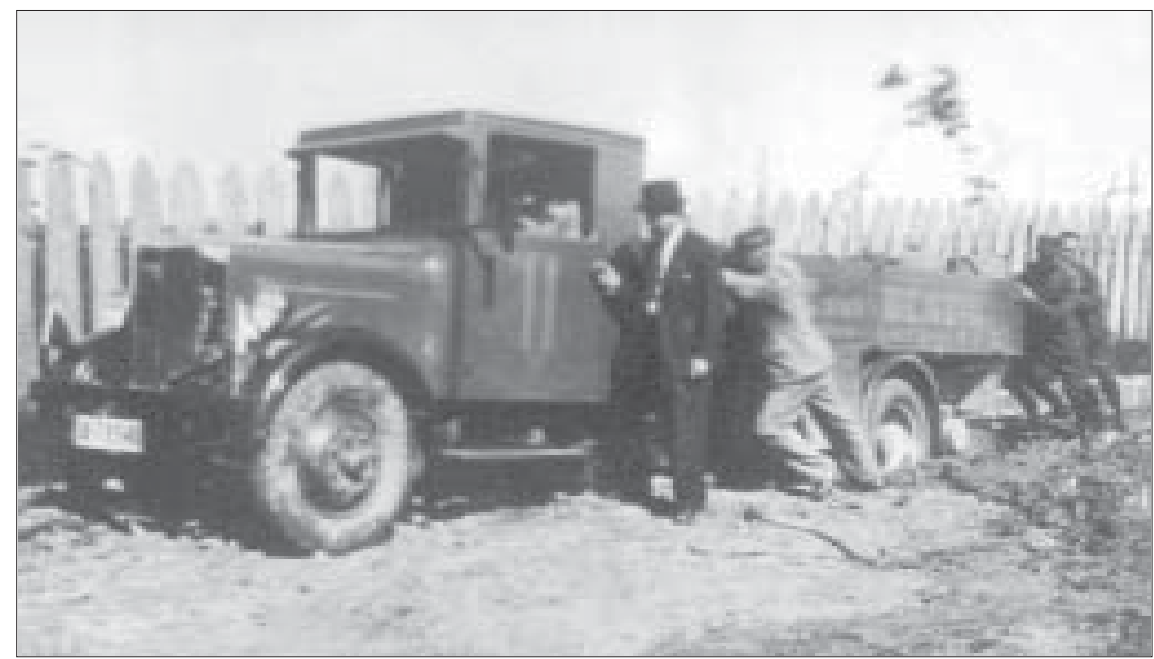

"Büssing N.A.G.” su dujų generatoriumi - pasiūlymas kariuomenei

Kai kariuomenès vadovybė nutarè, kad kariuomenès ūkiui papildyti reikalingiausios naujos sunkiojo transporto priemonès, buvo paskelbtas konkursas pirkti 45-60 sunkvežimių. Kariuomenės poreikiams buvo nutarta pirkti 3-6 t keliamosios galios sunkvežimius. Kaip ir kiekvieną kartą, buvo išsiuntinèti siūlymai pateikti parduodamų transporto priemoniu techninius duomenis, kainas ne tik Lietuvos verslininkams, bet ir užsienio gamintojams. Netrukus buvo sulaukta ịvairių firmų ir jų atstovų siūlymų. Vieną, "Amerikos lietuvių akcinès bendrovės" siūlymą, trumpai paminèsiu.

"Amerikos lietuvių akcinė bendrovè", nuo $1921 \mathrm{~m}$. atstovaudama "Ford" interesams Lietuvoje, plètojo ịvairiapusę prekybinę veiklą ne tik parduodama automobilius, bet ir traktorius bei kitas prekes. Ketvirtajame dešimtmetyje Lietuvą automobiliai pasiekdavo iš Kopenhagos, kur buvo surinkimo gamykla, ir patekdavo ị Kaune ịsikūrusio "Amlito" (taip

581936 m. gegužès mèn. auto rinktinès mašinų sąrašas, LCVA,F.1364,AP.1,B.456,L.98-99. 
populiariai buvo vadinama ši bendrovė) patalpas Kęstučio g. 44 a. Be prekybos amerikietiškais automobiliais , "Amlitas" vertèsi parduodamas ir "Mercedes Benz" lengvuosius automobilius bei sunkvežimius. Šiai bendrovei prekyba transporto priemonėmis sekèsi geriau nei kitomis prekémis, nes vos tik kariuomenė skelbdavo konkursą naujiems automobiliams i̊sigyti, kiekvieną kartą jame dalyvauti buvo kviečiamas "Amlitas".

"Amlitas" kariškiams pasiūlè keturis skirtingus "Mercedes Benz LG" serijos sunkvežimius: po du "Mercedes Benz LG 4000" ir "Mercedes Benz LG 3000" modelių variantus. Visi šios serijos "Mercedes Benz" sunkvežimiai turejo tris ašis. $6 \times 6$ tipo "Mercedes Benz LG 4000" buvo siūlomi du variantai, kurie galejo turèti dyzelini 95 AJ 2000 aps/min arba karbiuratorini 100 AG 2000 aps/min variklius. Śio modelio abiejų variantų kiti techniniai duomenys nesiskyrè, tik dyzelinis "Mercedes Benz LG 4000” kainavo beveik 50 tūks. Lt, o su karbiuratoriniu varikliu - keletu šimtų litų pigiau. Lietuvos kariuomenei buvo pristatytas sunkvežimio eksportinis modelis, kuris Vokietijoje nebuvo naudojamas.

6×4 tipo "Mercedes Benz LG 3000" buvo siūlomas pirkti su tokiais pat kaip ankstesnio modelio varikliais. Sunkvežimiai buvo skirtingos keliamosios galios: "Mercedes Benz LG 4000" - 4-5 t, o antrasis “Mercedes Benz LG 3000” - 3-4 t. Abiejų serijų sunkvežimiai skyrėsi važiuoklès svoriu, pavarų skaičiumi bei padangų dydžiu, pasiekdavo skirtingą maksimalų greitị. Pasiūlytojo modelio sunkvežimiai nebuvo nupirk-

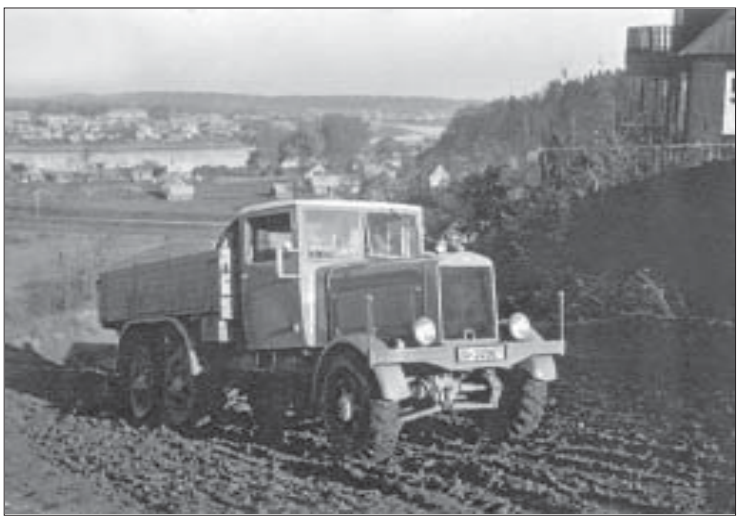

"Mercedes Benz" bandymų metu kopia ị kalną ti, tačiau vienas "Mercedes Benz L 2500" su dyzeliniu varikliu buvo isigytas ${ }^{59}$.

"Amlitas" turèjo atstovo teises parduodant amerikietiškus "Ford" automobilius Lietuvoje, tad antras jo pristatytas kariškiams automobilis buvo triašis $6 \times 4$ tipo "Ford 79157 ”. Kariškiams pa-

591939 rugsėjo 18 d. prièmimo aktas Nr.102, LCVA,F.1364.AP.3,B.534,L.120. 
siūlyto "Fordo" keliamoji galia buvo 4 t. Automobilyje buvo įtaisytas karbiuratorinis V-8 tipo 80 AG 3000 aps/min variklis, sunkvežimis pasiekdavo maksimalų $70 \mathrm{~km} / \mathrm{h}$ greitị. Ši kartą iš visų pasiūlytųjų šio sunkvežimio kaina buvo pati mažiausia. Suprantama, kad vairuotojo kabiną ir kẻbulą, kaip ir kitų anksčiau įsigytų kariuomenès automobilių, būtų reikèję pagaminti kariuomenès centrinèse dirbtuvèse. Kartais kariškiai užsakydavo verslininkų dirbtuvėse pagaminti sunkvežimių kẻbulus. 1939 m. gegužès 17 d. kariuomenė sanitarinių sunkvežimių (ant "Ford 91Y" važiuoklių) kẻbulus užsakẻ V.Kliokio dirbtuvėse ir už kiekvieną jų sumokèjo po $4765 \mathrm{Lt}^{60}$.

Be "Amerikos lietuvių akcinès bendrovès", turinčios didžiausią transporto priemoniu prekybos apimtị ir patirtị, sunkvežimiais Lietuvoje prekiavo ir kitos bendrovès bei verslininkai. Lietuvos kariuomenei buvo siūloma ịsigyti ịvairių transporto priemonių. "Inžinierius Salevskis ir bendrovè" siūlè "MAN E 2" sunkvežimius, atsargos karininkas K.Martinkus - "FWD MJ6" ir "FWD SU", Kurkauskas - "Crossley IGL 8" , bendrovė "Br.Tilmansai ir Co" - "Henschel 33D1", bendrovè "Autoimport" triašius eksportinius "Büssing NAG KB" ir "KV" bei sunkų dviaši 6,5 t. "654-FV6", aviacijos atsargos majoras J.Pyragius - "GAZ-AA". Čekai siūle pirkti puikius techniškai tobulesnius "Škoda 6" ir " $6 \mathrm{~V}$ ".

Plačiai kariuomenès naudojami "Fiat" markès sunkvežimiai buvo patvarūs, jie ir 1936 m. tenkino kariuomenès transporto poreikius. Tiesa, šių sunkvežimių keliamoji galia buvo tik 1,5 t, tad kariuomenės poreikiams patenkinti buvo pradėta ieškoti didesnès keliamosios galios sunkvežimių.

Nors kariuomenès biudžetas ketvirtajame dešimtmetyje, palyginti su kitų valstybės institucijų, buvo nemažas, tačiau kiekvieną kartą perkant automobilius ar kurią nors kitą techniką svarbiausia buvo kaina. Antras privalumas - perkamos technikos techniniai duomenys. Jie paaiškẻdavo praktiškai išbandant techniką, jei tokia technika buvo anksčiau pirkta - apibendrinant eksploatacijos duomenis. Transporto priemonių kaina dažnai sumažindavo kariškių apetitą, nes technikos reikejjo daug, o pinigų tam niekada nebuvo skiriama tiek, kad būtų galima patenkinti visus poreikius.

Karo technikos viršininkas K.Joniūnas 1936 m. spalio 1d. kreipėsi i kariuomenès vadą, priekaištaudamas ir primindamas, jog dar 1935 m. pateikęs raportą ir siūlęs, kokių reikètų imtis priemonių, kad krašte daugètų karo reikalams tinkamų automobilių. Pulkininkas leitenantas K.Jo-

${ }^{60}$ Užsakymas 1939 m. gegužès 17 d., LCVA,F. 1364, AP.3,B.537,L.27. 
niūnas pabrèžè, kad "šiuo metu auto priemonių skaičius krašte nerodo tendencijos didèti ir priešingai, tinkamų kariuomenès reikalams automobilių skaičius kas kart mažėja"61. K.Joniūnas apgailestavo, kad su Kariuomenės štabo IV skyriaus lydraščiu minėtas raportas buvo grąžintas ir pranešta, jog tuo tarpu jokių konkrečių žygių nepadaryta.

Dideli muitai stabdè naujų transporto priemonių pirkimą. $1934 \mathrm{~m}$. už ivvežamo ị šali lengvojo automobilio ( iki $1000 \mathrm{~kg}$ ) vieną svorio kilogramą reikèjo mokèti $2,5 \mathrm{Lt}$, automobilio nuo $1000 \mathrm{~kg}$ iki $1200 \mathrm{~kg}$ - $3 \mathrm{Lt}$, automobilio nuo $1200 \mathrm{~kg}$ iki $1600 \mathrm{~kg}$ - $4 \mathrm{Lt}$ ir daugiau kaip $1600 \mathrm{~kg}$ - 4,5 Lt. Kariuomenei perkant gaisrininkų automobilius, automobilius-cisternas, už kilogramą svorio tekdavo mokèti 2,00 Lt, perkant važiuokles - 0,75 Lt. Atlikta kariuomenės tyrimų komisijos muitų tarifų, muitų atskiroms transporto priemonėms ir mokesčių analizè rodè, kad dažnai sumokẻtas muitas priartėavo prie automobilio kainos, o perkant automobilius, kurie svèrè daugiau kaip 1600 kg, muitas būdavo didesnis už mašinos kainą. Daugiausia muito mokesčių sumokèta už lengvuosius automobilius "Buick" - 10719 Lt, už "Graham” - nuo 3570 Lt iki 5968 Lt, už sanitarinio sunkvežimio "Morris" važiuoklę - 1257 Lt ( su kèbulu - 10 282,50 Lt), už sunkvežimių "Ford" važiuoklę - 1 679,65 Lt, "ZIS" važiuoklę - 2 703,75 Lt. Kad būtų skatinama automobilius pirkti ir naudoti, kariškiai siūlè sumažinti muitus bei motorino (motorinu Lietuvoje buvo vadinamas benzino ir spirito mišinys) kainą (sumažinant muitą benzinui) ir mokẻti vienkartines kompensacijas Krašto apsaugos ministerijos proteguojamų firmų bei tipų automobilių savininkams. Sios priemonès turèjo būti taikomos tik naujiems lengviesiems automobiliams ir sunkvežimiams.

Karo technikos viršininkas brigados generolas leitenantas K.Popeliučka 1936 m. lapkričio 14 d. kreipdamasis ị kariuomenès štabo viršininką pulkininką J.Černių, išdèste savo siūlymus, kurie būtų naudingi, plečiant ir skatinant Lietuvoje motorizaciją. K.Popeliučkos nuomone, Lietuvoje turètų vyrauti transporto priemonès su benzininiais varikliais, nes pritrūkus benzino būtų galima naudoti pakaitalą - benzino ir spirito mišini. Kalbėdamas apie automobilių ịvežimą, jis siūlè proteguoti sunkvežimių su dujų generatoriais importą bei sumažinti muitus, o motorino kainą sumažinti iki 0,6 - 0,7 Lt už litrą. Generolas leitenantas K.Popeliučka, kaip ir nemažai to meto Lietuvos technikos specialistų, buvo nusistatęs prieš automobilių su dyzeliniais varikliais plitimą krašte, o kad bū-

${ }^{61}$ LCVA, Ap.1, b.456, 1,.125 
tų galima padidinti perkamų sunkvežimių skaičių, siūlè proteguojamų bei kariuomenės tikslams reikalingų modelių automobilių pirkẻjams mokèti kompensacijas. Jo nuomone, kariuomenès poreikius tenkintų 1,5 t, $3 \mathrm{t}$ ir $5 \mathrm{t}$ keliamosios galios sunkvežimiai su benzininiais varikliais, ypač tie, kurie bus su dujų generatoriais ${ }^{62}$.

Kapitonas B.Bartkevičius rašè, kad "mūsų auto ūkis nepatenkinamai buvo tvarkomas" ir "net iš Pabaltijo valstybių tarpo atsidūrème netinkamoje sau vietoj". Jis teigè, kad automobilių ịvežimu paliekama rūpintis kelių firmų atstovams, "kurių tarpusavis rungtyniavimas remiasi konkurencinių kainų derinimu”, o rinkos rungtynes laimėti turi šansų "ivvairūs benzininiais varikliais automobiliai, kurie savo krašte yra nepageidaujami ir ujami”. Kapitonas B.Bartkevičius, apžvelgęs ketvirtojo dešimtmečio didžiųjų pasaulio šalių transporto vystymąsi ir kuro naudojimo klausimus, priejo išvadą, kad visos Europos valstybès stengiasi nelikti priklausomos nuo benzino ir ieško alternatyvų. Jis pabrěžia, kad pramoninèse šalyse lengviesiems automobiliams stengiamasi naudoti sintetinị benziną arba benzinas skiedžiamas vietiniu spiritu. Žemès ūkio šalyse naudojamas benzino ir spirito mišinys (motorinas). Sunkiajam transportui - sunkvežimiams - vis dažniau buvo naudojami dyzeliniai varikliai bei automobiliai su dujų generatoriais, o transporto ūkis standartizuojamas ${ }^{63}$. Kapitono B. Bartkevičiaus galva, geriausia būtų, jei "mūsų ūkio tvarkymą galètų atlikti [...] valstybès kapitalui dalyvaujant, bendrové, kuri tą ùkio šaką tvarkytų, atsižvelgdama i krašto saugumo ir kitus krašto reikalus”.

Nuo 1937 m. pakeisti muitų tarifai buvo palankesni įvežant naujus automobilius. İvežant lengvajị automobilį su dujų generatoriumi, už $1 \mathrm{~kg}$ automobilio svorio teko mokèti 1,50 Lt, su dyzeliniu varikliu - 2,50 Lt, lygiai tiek pat reikejo mokèti už importuojamus visų svorio kategorijų lengvuosius automobilius su benzininiais varikliais. Už įvežamą krovininị automobilį su dujų generatoriumi buvo nustatytas muito mokestis $1 \mathrm{Lt}$ už kilogramą, o su dyzeliniu varikliu - net 3,50 Lt už kilogramą. I Lietuvą įvežant krovininių automobilių važiuokles su dujų generatoriumi, už vieną svorio kilogramą reikèjo mokèti $1,00 \mathrm{Lt}$, o už dujų generatoriaus $1 \mathrm{~kg}$ - 0,50 Lt, važiuokles su dyzeliniu varikliu - 0,75 Lt ${ }^{64}$.

Valstybei sumažinus importo muitus, šalies rinkoje padaugejo įve-

\footnotetext{
${ }^{62}$ LCVA, F 1364, AP.1, B. 456, L. 131.

${ }^{63}$ Mūsų žinynas , 1937 m., vasaris Nr.2, psl. 156 - 165.

${ }^{64}$ Lietuvos muitų tarifai, Kaunas, Spindulio sp-vè, 1940 m., psl.123 - 124. 
žamų automobilių, motociklų ir jų atsarginių dalių. $1936 \mathrm{~m}$. buvo ịvežta 564,3 t šios grupès prekių, o 1937 m. - jau 2146,3 t (1936 m. nupirkta už 2462,8 tūkst. Lt, o 1937 m. - jau už 8845,9 tūkst. Lt) ${ }^{65}$. Šis sprendimas buvo labai reikalingas bei naudingas, nes prisidèjo ir prie karinès technikos atnaujinimo, ir prie civilinio transporto plètojimo.

Lietuvos kariuomenejje taip pat buvo sunkvežimių su dujų generatoriais. 1937 m. kariuomenè iš Švedijos įsigijo dešimt dviašių 4,5 t keliamosios galios "Volvo LV 94 D" markès automobilių važiuoklių su "Örebro" dujų generatoriais. Atvežtiniai automobiliai turejjo mažų defektų bei komplektavimo spragų, tad tiekėją J. Hultströmą teko ịpareigoti per mėnesi trūkumus pašalinti. Už šiuos sunkvežimius bendrovei "Aktiebolaget Volvo Göteborg” buvo sumokèta 79206 švedų kronos. Be minètų "Volvo LV 94 D”, kuriuos įsigijo kariuomenè, J. Hultströmas dar siūlẻ pirkti keletą kitų "Volvo LV" 79, 83, 84 ir 93 modelių, tačiau jų Lietuvos kariškiai nenupirko. Taip pat kariuomenei buvo siūloma pirkti vokiškus sunkvežimius "Büssing N.A.G. " su dujų generatoriais. I Lietuvą buvo atsiųsta pademonstruoti sunkvežimį su šia ịranga ir kariškiai po svarstymų nutare pirkti pasiūlytus "Bssing N.A.G." bei sunkvežimius "Volvo". Tiesa, dèl dar nežinomų priežąsčių, be dešimties "Volvo" su dujų generatoriais, kariuomenèje atsirado tik vienas "Büssing N.A.G."

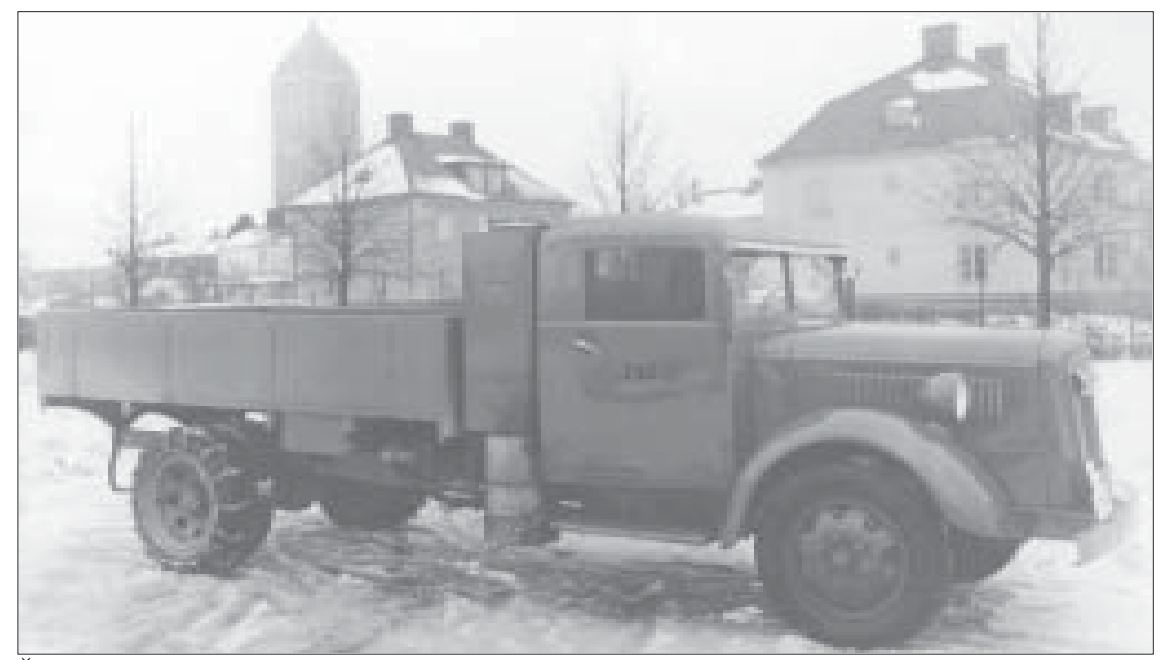

Švedų pasiūlymas - "Volvo" su dujų generatoriumi

${ }^{65}$ Ekonomika, Kaunas, 1938 m. , Nr. 2(14), psl.143. 
Kariuomenei siūlẻ savo sunkvežimius ir firmos gamintojos: "Saurer $(8 \times 8$ tipo) $8 \mathrm{M}$ " , $6 \times 6$ tipo " $6 \mathrm{M}$ " ir $6 \times 4$ tipo "CRD" , "Leyland $(6 \times 4$ tipo) TS E8" ir "KZDX" , "Austro -Daimler $(6 \times 6$ tipo) ADAZ" bei $6 \times 4$ tipo "ADGR", "Thornycroft $(6 \times 4$ tipo) WF/AC6/1, WF/AC4/ bei IETC4 “, "FIAT/SPA (6×4 tipo) Dovunque 35”, "WHITE $(4 \times 2$ tipo $) 700$ 60". Pasiūlytuosius “Morris $(6 \times 4$ tipo) Commercial CD” kariuomené nupirko ir pradèjo naudoti $1933 \mathrm{~m}$.

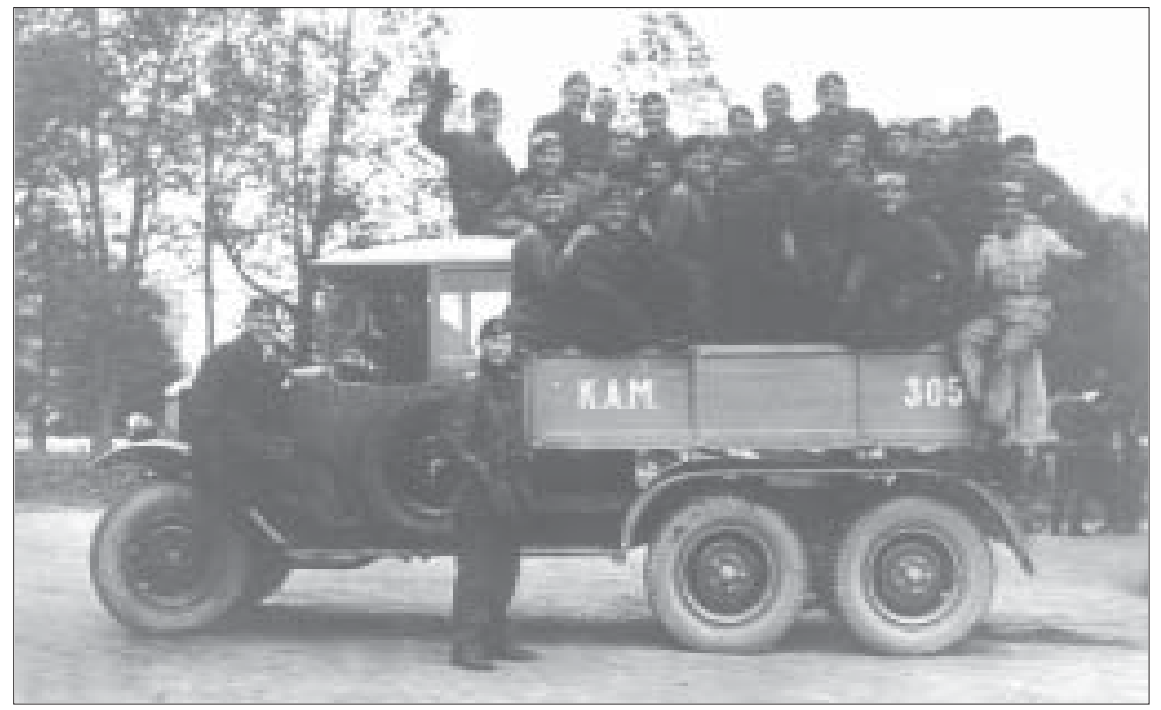

Aviacijos “Commercial CD” $1931 \mathrm{~m}$.

Siūlomi sunkvežimiai buvo labai skirtingi. Jau trečiajame dešimtmetyje daugelis sunkvežimių gamintojų suprato, kad neverta tikètis sẻkmingų pardavimo sutarčių su kariškiais, jiems siūlant sunkvežimị su vienu varomuoju tiltu. Gamintojai šiuos sunkvežimius aprūpindavo 4-6 cilindrų karbiuratoriniais (rečiau - dyzeliniais) varikliais, o keliamoji galia buvo mažesnè nei triašių sunkvežimių. Žinant, kad kariuomenei reikia didesnio pravažumo technikos, firmos daugiausia siūlè sunkvežimius su dviem (kaip "FWD MJ6") varomaisiais tiltais. Dar kitos firmos pasiūlè modelius su trimis varomaisiais tiltais, tai "Mercedes Benz LG 4000", o "Saurer 8M" buvo ne tik keturių varomųjų tiltų, bet ir su automatiškai blokuojamais diferencialais. Kai kurie sunkvežimiai buvo komplektuoja- 
mi su gerve automobilio gale ar priekyje. Iš siūlomų ịsigyti sunkvežimių tik retas turèjo dyzelini variklį, dažniausiai buvo benziną naudojantys varikliai. Kiekvieno iš siūlomų pirkti sunkvežimių kaina irgi buvo skirtinga, nes priklausẻ ne tik nuo komplektacijos, bet ir nuo konkretaus sunkvežimio techninių duomenų.

Kariuomenei buvo siūloma pirkti jau anksčiau išbandytus ir pateisinusius kariškių lūkesčius angliškus "Leyland KZDX" sunkvežimius, kuriuos ji jau buvo pirkusi iš verslininko A.Kruglovo $1932 \mathrm{~m}$. Minètos markès sunkvežimiai buvo eksploatuojami karo aviacijos dalyse ir laikomi tikrai patikimais automobiliais. Be šiu sunkvežimių, karo aviacijoje buvo naudojami "Morris Commercial CD", dviašiai bei triašiai "Ford" bei "Zis".

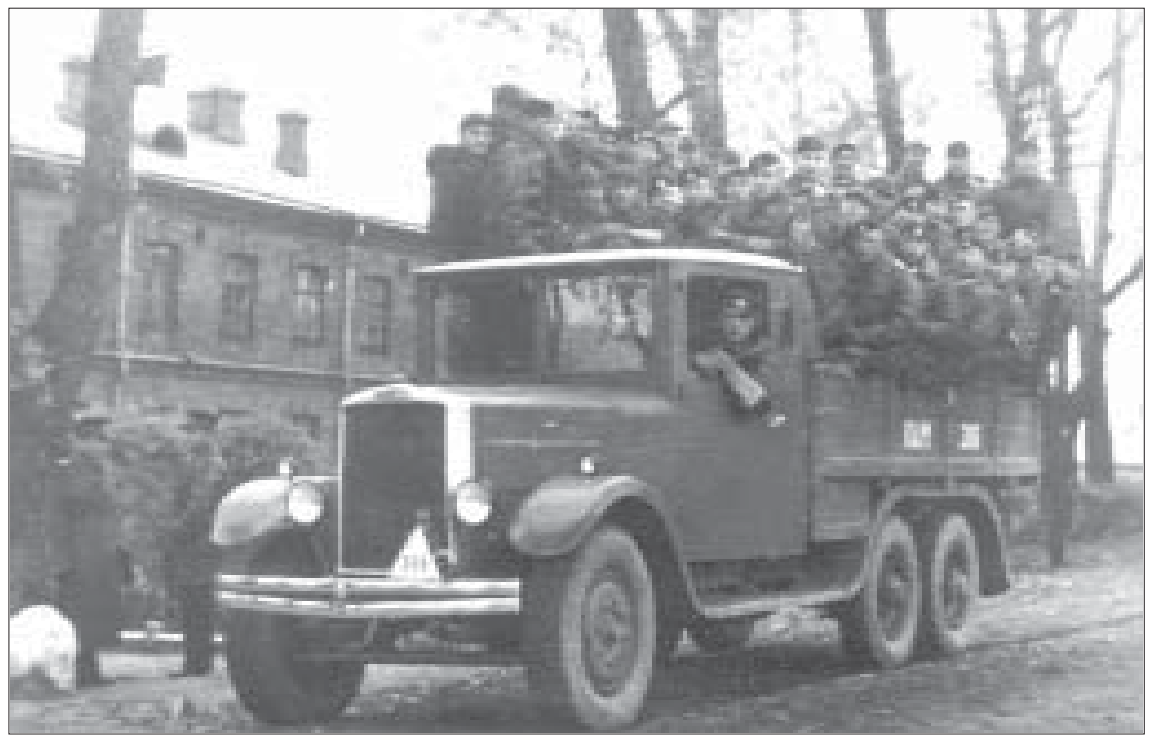

"Leyland KDXZ" - aviacijai

Laikinasis karo technikos viršininkas pulkininkas P.Kutka kartu su Tiekimo skyriaus viršininku pulkininku inžinieriumi B.Aleksandravičiumi 1939 m. liepos 22 d. raštu Nr. 23357 kreipèsi i kariuomenès tiekimo viršininką ir pateikè parengtus užsakymo pirkti automobilius iš "Amlito" dokumentus. Kartu pateiktoje lenteleje nurodoma, kad automobilių rinktinei reikètų 10 lengvụjų automobilių (perkama 7), kavalerijai - 5 (tiek ir 
perkama), o įvairioms kitoms kariuomenès dalims - 410 (!), kai tuo tarpu perkama 13 sunkvežimių ${ }^{66}$. Vadinasi, galima teigti, kad bene pirmą kartą buvo nurodyta, kiek automobilių reikètų kariuomenei.

Rašydamas apie automobilių transportą, majoras J. Liūga pažymèjo: "turèdami pakankamą tinklą plentų, 1 ir 2 rūšies vieškelių, [...] per mažai turime autovežimių ( sunkvežimių-V.G.) - tik 40 - 50\% mūsų šiaurès kaimynų autovežimių skaičiaus”. Kalbėdamas apie geležinkelių tinklo ir šio transporto panaudojimą karo veiksmuose, jis šia susisiekimo priemone abejojo: "prie dabartinių karo aviacijos puolimų mūsų aplinkybėse ne visai patikima (pasikliauti ten esančia technika- V.G.)”. Apsaugai nuo puolančiųjų siūlè "turèti labai pajègią aviaciją ir priešlejktuvinę apsaugą" 67 . Reikiami sprendimai šiuo klausimu buvo priimti, tad priešlèktuvinė apsauga 1940 m. liepos ménesi jau turèjo trisdešimt šešis "ZIS-6" markès su karbiuratoriniais 73 AG./2300 aps/min varikliais bei dvylika "Ford" sunkvežimių ${ }^{68}$. Galima pasakyti, kad vienintelè priešlèktuvinès apsaugos rinktinè buvo visiškai motorizuota ${ }^{69}$ ir neatsiliko nuo kitų šalių mobilumo standartų. Be "Ford", turèta ir dešimt "Chevrolet", keletas "GMC" autromobilių 70

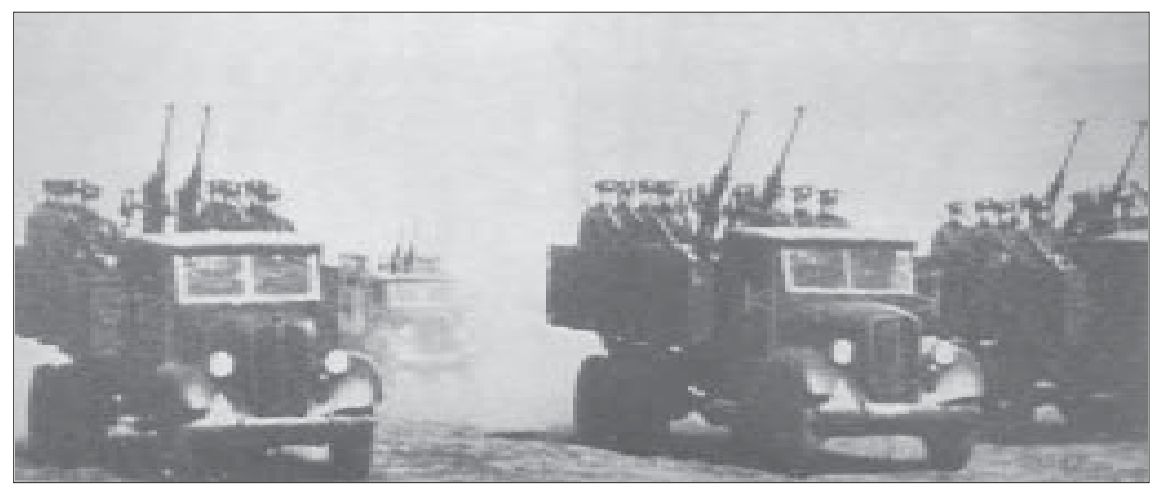

Priešlėktuvinès apsaugos rinktinès "Ford"

\footnotetext{
${ }^{66}$ LCVA, F 1364, AP.3, B. 534, L. 76 a.p.

${ }^{67}$ Kardas,1940 m. vasario 1 d.,Nr.3,psl.74-76.

${ }^{68} 1940$ m.liepos 1d.priešlèktuvinès apsaugos rinktinès sunkvežimių ir vidaus degimo variklių sąrašas,LCVA,F.1364,AP.3,B.432,L.174.

${ }^{69}$ G.Surgailis Lietuvos kariuomenè 1918-1998, Vilnius 1998,psl.47.

701940 m. liepos 1 d.sąrašas, LCVA, F 1364, AP. 3, B. 432, L. 174.
} 
Lietuvos kariuomenè dažniausiai naudojo transporto priemones su karbiuratoriniais varikliais. Tai lėmė ne tik aukščiausios karinès vadovybès neigiamas požiūris ị transporto priemones su dyzeliniu varikliu, bet ir didesnè dyzelinių automobiliu kaina.

Kariuomenès inžinerijos I ir II batalione buvo naudojami triašiai "Zis -6". Sovietu sajunga, kurios firmos V/O "Technoimport" atstovas Kaune buvo J.Slavinas, $1940 \mathrm{~m}$. Lietuvos kariuomenei siūlè issigyti 3 tonų "Zis -14" bei "Zis -5 "71. Kariuomenè pasirinko ant "Zis -5 " važiuoklès įrengto benzinvežio (kartu su siurbliu) variantą ir šešis užsakẻ karo aviacijai. Pristačius juos ị Kauną, paaiškejo, kad jie turi komplektavimo trūkumų bei kitụ defektų. Iš V/O "Technoimport" firmos atstovo buvo pareikalauta defektus ištaisyti.

Kurị laiką, ypač trečiaji dešimtmetị, automobilių rinktinėje buvo paplitę "Fiat" sunkvežimiai, kurie dèl nesudètingos konstrukcijos ir pigios eksploatacijos labai tiko to meto kariškių poreikiams. Ketvirtajame dešimtmetyje buvo irgi siūloma ịsigyti "Fiat/SPA 38 R" sunkvežimius. Šarvuočių rinktineje naudojamasi "Chevrolet", "Saurer", "Ford", "Morris Commercial", "Fiat" bei trofejjiniais "Polski Fiat" sunkvežimiais.

Kariškių pastangos ịsigyti naujų sunkvežimių nenuejjo veltui. Laikinasis karo technikos viršininkas J.Barzda-Bradauskas $1937 \mathrm{~m}$. gruodžio $18 \mathrm{~d}$. rašte nurode, kad per metus ịsigyta trisdešimt nauju dviašių 2-3 t sunkvežimių " Ford" bei toks pat kiekis naujų 3-4 t krovos triašių "Ford". Tarp ịsigytų transporto priemonių buvo dešimt naujų 4,5 t krovos dviašių "Volvo" sunkvežimių su dujų generatoriais ir šešiasdešimt naujų 4 t krovos triašių "Zis-6". Jis pažymejjo, kad norint užbaigti metinę kariuomenès aprūpinimo transportu programą, reikètų iš laimėjusių konkursą firmų nupirkti dar keturiolika sunkvežimių važiuoklių ir penkias priekabas. Krašto apsaugos ministras pulkininkas St.Dirmantas patvirtino šią paraišką ${ }^{72}$.Šių sunkvežimių kẻbulai ir kabinos buvo pagamintos Kauno dirbtuvèse.

\footnotetext{
${ }^{71}$ Prièmimo aktas 1940 m. lapkričio 16, LCVA, F.1364,AP.3,B.529,L.94.

$721937 \mathrm{~m}$. gruodžio 18 d. karo technikos viršininko raštas $\mathrm{Nr} .11250$, LCVA, F.1364,AP.3,B.398,L.246-246A.P.
} 
1939 m. savo darbe Generalinio štabo karininkų 3 laidos kursantas Generalinio štabo pulkininkas A.Šova rašè, kad "gyvename valstybių ginklavimosi lenktyniavimo laikotarpi”. Jis, prognozuodamas būsimojo karo perspektyvas, pabréžè, kad "mums reikia daug

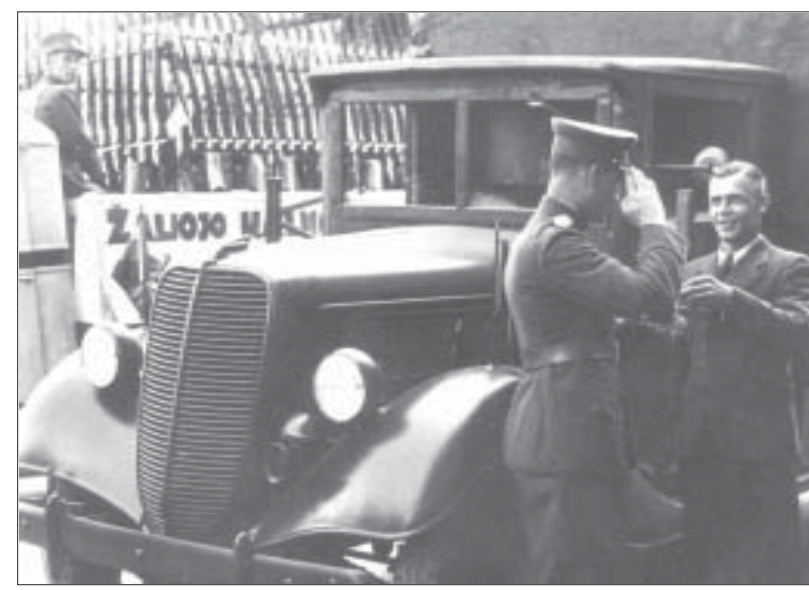

Ketvirtojo dešimtmečio "Ford"

techniškų priemonių, nes moderninis karas kaip tik šių priemonių gausumu ir pasižymès”. Galima teigti, kad pulkininkas A.Šova, bene geriausiai suprasdamas Lietuvos kariuomenès motorizavimo ir mechanizavimo poreikị, siūle "krašte sudaryti reikiamus motorizacijai plèstis pagrindus". Iš dalies tai buvo padaryta 1937 m. sumažinus muitus, tačiau valstybejje, pasak pulkininko A.Šovos, "kyla reikalas vykdyti gerą ir planingą automobilizmo politiką, apimančią jau taikos metu visos valstybės gyvenimą”. Jis rašè, jog "su džiaugsmu tenka konstatuoti, kad paskutiniaisiais metais ginklavimosi srityje padarème ir mes didelę pažangą, bet tuo nesitenkinant reikia skubèti ginkluotis, nes priešingai galime pavèluoti" 73 , visgi reikiamų, kardinalių sprendimų nebuvo padaryta. Pulkininko A. Šovos darbe išsakytos mintys nebuvo išgirstos aukščiausių valstybės politikų sluoksnių, o ir esamai padèčiai pakeisti pritrūko laiko bei materialinių išteklių.

Kariuomenès automobilių junginiui (jam plečiantis pavadinimas nuolat keitèsi: iš pradžių tebuvo kuopa, o sunaikinant kariuomenę - automobilių rinktinè) vadovavo karininkai Sergejus Fanstelis, Adomas Daugirdas, Kazys Joniūnas, Vladas Aužbikavičius, Kazys Babickas. Laikinai teko vadovauti ir kitiems kariškiams. Kaip ir kitos kariuomenès dalys, automobilininkai turėjo savo šventę, kurią švęsdavo rugsėjo $5 \mathrm{~d}^{74}$

\footnotetext{
${ }^{73}$ Pulk..A.Šova Kariuomenès organizavimas,LCVA, F. 506, AP. 1, B. 243.,L.5-14.

${ }^{74}$ İsakymas kariuomenei Nr.138, 1927 m. gruodžio $3 \mathrm{~d}$.
} 
Dar 1919 m. balandžio mėnesị buvo nustatyta, kad inžinerijos bataliono specialiosios kuopos (taip pat automobilių bei motociklų) kariai antpečiuose turi nešioti skiriamuosius ženklus. Tiesa, dar nepasisekẻ nustatyti, kaip jie atrode ir ar išvis buvo nešiojami ${ }^{75}$. Automobilininkai, kaip ir kitų tarnybų kariškiai, turẻjo uniforminį specialybės ženklą - geltonos spalvos automobilio vairą.

Reikia pažymėti, kad visi kariuomenès perkami automobiliai buvo îsigyjami perkant tik važiuokles su variklio dangčiu, priekiniais sparnais bei varikliu, o kabinos ir kèbulai buvo gaminami Kaune centrinèse kariuomenès, "Amerikos lietuvių prekybos akcinès bendrovés" bei J.Hulströmo dirbtuvėse. Pastarosioms nespejant tenkinti kariuomenės užsakymų, kẻbulams gaminti buvo pasitelkiami ir kiti verslininkai.

Prieš pat sovietų okupaciją Lietuvos kariuomenès automobilių ūkis buvo smarkiai atnaujintas, pasenusių modelių transporto priemonès pakeistos ị naujesnes. Didesne dalis buvo sunkvežimiai, ic intendantūros sandèlius perduoti atsargai. Daugiausia Lietuvos kariuomenèje buvo naudojami "Ford 79", "Ford 73", "Ford Sussex BB 157”, "Ford 79-157”, "Ford 79", "Volvo LV 94", "Zis - 6", "Zis - 5", "Fiat", "Leyland KDSX J", "Büssing NAG”, "Morris Comercial” sunkvežimiai" ${ }^{76}$.

Tarp kariuomenès naudojamo transporto pasitaikydavo techniniu požiūriu retesnių, įvairesnių tipų. Pvz., 1921 m. įsigytas gaisrinis automobilis "Praga"77, 1937 m. organizacija "Jaunoji Lietuva" kariuomenei padovanojo keturis triračius "Framo-Werke" automobilius, kurie buvo perduoti naudotis 1 kavalerijos pulkui. Lietuvos kariuomenejje daugiausia buvo naudojami amerikietiški sunkvežimiai, kiek mažiau - sovietų ir italų, kitų šalių minètų transporto priemonių buvo visai nedaug. Specialioji technika ịvairiu kariuomenės egzistavimo laikotarpiu buvo ịtaisyta ant skirtingų sunkvežimių važiuoklių. 1927 m. sanitariniams automobiliams buvo panaudotos “Audi”, "Ley”, "Mercedes Benz” sunkvežimių važiuoklès ${ }^{78}, 1940$ m. - sanitariniai automobiliai įrengti ant "Ford 91Y", "Morris

\footnotetext{
75 Vaičenonis J.Lietuvos kariuomenès uniformos istorija 1918-1940m.,Lietuvos archyvai,1999/ 12,Vilnius, 1999 m.psl.52.

${ }^{76}$ Grigoraitis V. Lietuvos kariuomenès automobiliai 1919-1940 m. Lietuvos archyvai,1999/ 12,Vilnius, 1999 m.psl.42.

771921 rugpjūčio 31 d.tiekimo skyriaus viršininko raštas Nr.8551, LCVA,F.1364,AP.1,B.30,L.25.

${ }^{78}$ Grigoraitis V. Lietuvos kariuomenès automobiliai 1919-1940 m. Lietuvos archyvai,1999/ 12,Vilnius, 1999 m.psl.30.
} 
Comercial C.S." važiuoklių, automobilių radijo stotys - "Morris Comercial D.S.", "Polski Fiat"79, aviacijos prožektoriai "Basse-Selve D90" sumontuoti ant sunkvežimio "Citroen" važiuoklès ${ }^{80}$.

Nuo 1940 m. birželio 15 d. šali okupavus sovietų kariuomenei, pradèta naikinti Lietuvos kariuomenę. $1940 \mathrm{~m}$. rugpjūčio 30 d. ịsakymo Nr. 0149 ( byloje - nuorašo nuorašas, patvirtintas 1940 m. rugpjūčio $31 \mathrm{~d}$. brigados generolo Sprangausko) 11 armijai 3 punktu buvo numatyta, kad Lietuvos kariuomenès automobilių transportą, turtą, kanceliarinius reikmenis perims sudaryta komisija. Komisijai vadovauti paskiriamas papulkininkis A.A. Sotalskis, nariai - papulkininkis Efremovas, kapitonas Barkunovas, vyr. politrukas Psitko bei Lietuvos kariuomenès atstovai. Darbą komisija turéjo baigti rugsẻjo $10 \mathrm{~d}$. Divizijos generolas S.Pundzevičius ši ịsakymą nusiunte vykdyti karo tiekimo viršininkui, o iš kariuomenès štabo ị komisiją atstovu paskyrė Generalinio štabo pulkininką leitenantą Mačioką ${ }^{81}$.

1940 m. rugsèjo 5 d. Karo technikos viršininko paskirta komisija (automobiliu rinktinès majoras J.Baranauskas (pirmininkas) ir nariai Karo technikos valdybos kapitonas A.Griškevičius ir Automobilių rinktinès leitenantas P. Variakojis) patikrino visus kariuomenès automobilius ir nustaté eksploatacijai leistiną keliamają galią bei prikrauto pilno sunkvežimio svorị. Tokia užduotis būtų suprantama kaip vienas iš sunkvežimiu krovumo norminimo darbų, tačiau kartu buvo suskaičiuoti lengvieji automobiliai, motociklai ir visa kita kariuomenès technika. Taip buvo inventorizuota kariškių turima technika, prieš ją perimant sovietu kariuomenei. Prie patikrinimo akto pridedamame sąraše, deja, neatspindinčiame realaus kariuomenės technikos kiekio, buvo vardijama technika, nurodant jos priklausomybę kariuomenès dalims. Sudarytame sąraše komisija suskaičiavo 2 kavalerijos pulko, 1, 3, 4, 8 pestininkų pulkų, Karo aviacijos, 1, 2 inžinerijos bataliono transportą, priešlèktuvinės apsaugos rinktinès, automobilių rinktinès, ryšiu bataliono, Karo mokyklos, ginklų sandèlio Linkaičiuose techniką. İ ši sąrašą buvo įrašyti 108 sunkvežimiai, 58 lengvieji automobiliai, 11 sanitariniu automobilių,

\footnotetext{
${ }^{80}$ V.Grigoraitis Lietuvos kariuomenès automobiliai 1919-1940 m. Lietuvos archyvai,1999/ 12,Vilnius, 1999 m.psl.35.

${ }^{81}$ LCVA, F R 222, AP. 1, B. 15, L. 27.
} 
4 šarvuočiai, 6 šarvuoti automobiliai, 12 "Renault" tankų, 24 tanketės "Vickers Carden Loyd", 14 traktorių ir daug kitos specialiosios technikos ${ }^{82}$.

1940 m. rugsèjo 14 d. rašte Nr. 21434 kariuomenès tiekimo viršininkui laikinasis karo technikos viršininkas pulkininkas leitenantas Sperauskas pranešè, kad buvusios Lietuvos kariuomenès dalyse yra 213 tinkamų naudoti sunkvežimių bei 150 remontuotinų. Tame pačiame rašte pabrěžiama, kad 29 Šaulių teritoriniam korpusui (toliau - 29 Š.T.K.) reikia 275 sunkvežimių, taigi trūksta 62 sunkvežimiự ${ }^{83} .1940$ m. rugsẻjo 17 d. rašte Nr. 92 sovietų 11 armijos štabo viršininkui buvo teigiama, kad Lietuvos kariuomenė turëjo 363 sunkvežimius ir 192 lengvuosius automobilius, iš jų 102 reikia rimto remonto. Pagal etatus 29 Š.T.K. taikos metu buvo būtini 29 lengvieji automobiliai, 263 sunkvežimiai, tačiau siūloma 40 vienetu daugiau nei nustatyta norma palikti lengvuju automobilių bei pažymėta, kad 40 sunkvežimių buvo perduota sovietų aviacijai ( oro uostų statybai) ${ }^{84}$.

Dalis Lietuvos kariuomenès sunkvežimių po šalies okupacijos ir aneksavimo perèjo ị sovietų kariuomenès rankas, buvo išvežta iš šalies, o kitos buvusios Lietuvos kariuomenės transporto priemonès prasidèjus karui jau kaip sovietinės kariuomenės nuosavybė pražuvo pirmụjų karo dienų mūšiuose.

\section{Išvados}

1. Lietuvos kariuomenès automobilių junginiai pradeda veiklą įsigydami naudotus automobilius. Dali transporto priemonių kariuomené perka naudotų, o kiti atitenka kaip kovų trofejjai. Automobiliai remontuojami, įrengiami garažai.

2. Pirmajij automobilių junginių veiklos dešimtmetị ịsigyta nedaug naujos technikos. Nupirkti tik itališki sunkvežimiai. Lietuvos kariuomenè naudoja įvairių šalių, ivvairių markių bei modelių automobilius. Kariniams vairuotojams ir motociklininkams mokyti ịkuriamas automobiliu kuopos mokomasis būrys. Važiavimo ịgūdžiams formuoti naudojamas pažangus mokymo metodas - važiavimo veiksmų imitatorius.

3.Antraji automobilių junginių veiklos dešimtmetị, ypač ketvirtojo dešimtmečio pabaigoje, intensyviau perkami nauji amerikietiški ir sovie-

\footnotetext{
${ }^{83}$ LCVA, F R 222, AP. 1, B. 15, L. 98.

${ }^{84}$ LCVA, F R 222, AP. 1, B. 15, L. 95.
} 
tiniai automobiliai. Naujiems automobiliams pirkti naudojama efektyvi atrankos sistema, iš pasiūlytos technikos, atsižvelgiant ì priimtiną kainą ir kokybę, pasirenkant geriausią.

4. Antraji automobilių junginių veiklos dešimtmetį automobilių techniką pradedama vienodinti, tačiau dèl Lietuvos okupacijos tai nepadaryta. Didžiausią kariuomenès transporto dalį sudaro amerikietiški, rusiški, vokiški ir itališki automobiliai.

5. Kariniam automobilių transportui registruoti naudojama karinio transporto registravimo sistema, parengiami automobilių technikos priežiūros, saugojimo ir naudojimo, mobilizacijos bei kiti norminiai dokumentai.

6. Vyriausioji kariuomenès vadovybė nèra protechniška, tad šis požiūris atsispindi motorizuojant bei mechanizuojant kariuomenę. Objektyviai situaciją lemia ne tik kariuomenès vadovybès požiūris, bet ir šalies ekonominis pajègumas.

7. Didesni kariuomenès vadovybès požiūrio pokyčiai, orientuoti i kariuomenès motorizavimą bei mechanizavimą, pastebimi prieš pat Antraji pasaulinị karą. Nors kariuomenès automobilių technikos kiekis nebuvo proporcingas kariuomenès dydžiui, tačiau ši technika buvo geros kokybės ir pakankamai moderni. Dèl karo Europoje bei pavėluotų vadovybès sprendimų kariuomenès technika nebuvo modernizuota iki galo.

8. Okupacinè kariuomenè, pasisavindama Lietuvos kariuomenès turtą, pasisavina ir sunkvežimius, lengvuosius automobilius bei motociklus, kitą specialiają techniką. Dalis automobilių technikos iš šalies išvežama, kita sunaikinama karo metu.

\section{Panaudotos nuotraukos:}

Lietuvos vaizdo ir garso archyvo, Lietuvos valstybès centrinio archyvo, Vytauto Didžiojo karo muziejaus, Aviacijos ir technikos muziejaus, asmeninio R. Senapėdžio archyvo 